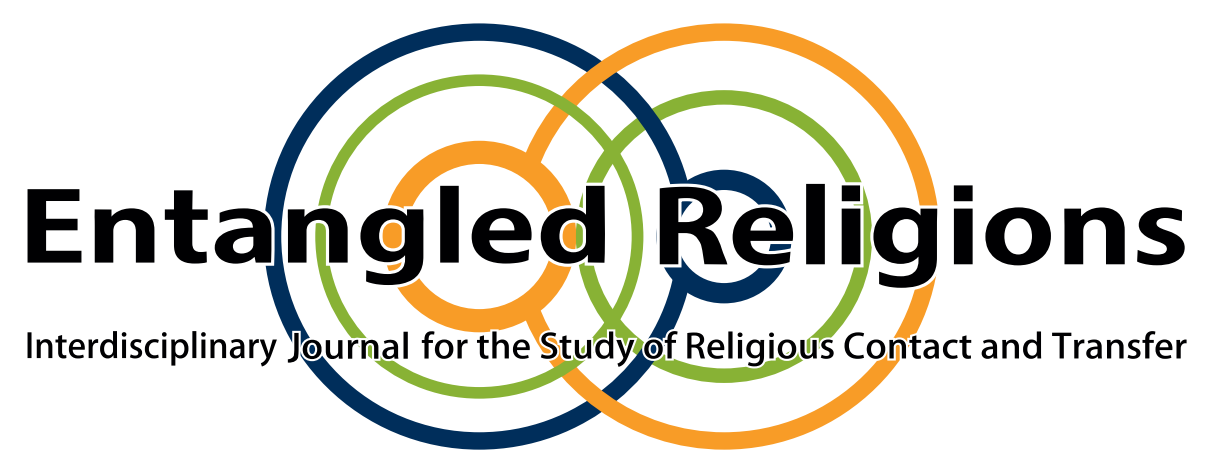

\title{
Towards a Multi-Religious Topology of Islam: The Global Circulation of a Mutable Mobile
}

MANFRED SING

Leibniz Institute of European History, Mainz, Germany

This contribution to Entangled Religions is published under the Creative Commons Attribution 4.0 International Public License (CC BY 4.0 International). The license can be accessed at https://creativecommons.org/licenses/by/4.0/legalcode.

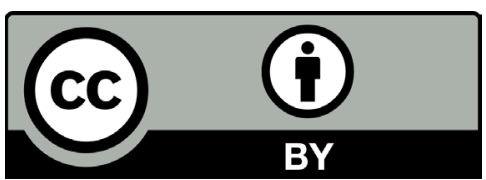

Entangled Religions 9 (2019) http://doi.org/10.13154/er.v9.2019.211-272
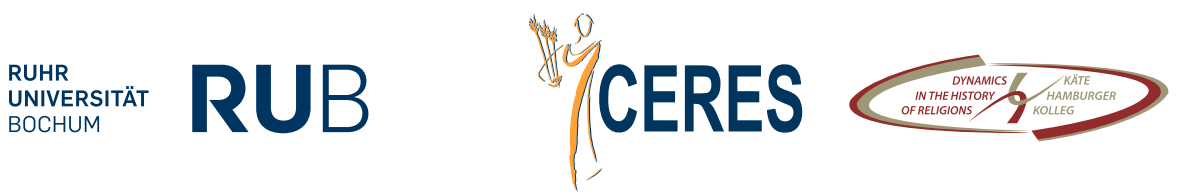

SPONSORED BY THE 


\title{
Towards a Multi-Religious Topology of Islam: The Global Circulation of a Mutable Mobile
}

\author{
MANFRED SING \\ Leibniz Institute of European History
}

\begin{abstract}
Narratives of the origins, the history, and the present state of Islam always entail spatial claims. Accordingly, Islam emerged in the Arabian Peninsula, spread over its so-called heartlands, and became a world religion. A common understanding inscribes Islam onto the Orient and opposes it to Europe, the Occident, or the West. Such spatial claims are faced with fundamental challenges and epistemological shortcomings because neither Islam nor space are naturally given, bounded entities. Rather, different historical actors and observers produce spatialized Islam. In this chapter, I challenge the notion that "Muslim space" is a useful analytical concept, and scrutinize the ways in which academic discourses inscribe Islam onto space and history. As an alternative, I propose a topology that understands the production of space as a multi-dimensional social process, including Muslim and nonMuslim perspectives at the same time. Thus, I delineate the topology of Islam as variegated, dynamic, and multi-religious from its inception. My argument is that Islam's trans-regional spread turned it into a polycentric, mutable mobile characterized by internal and external diversity. I further argue that images of Islam are an integral, yet often concealed part of European and Western knowledge production and self-understanding. Epistemologically, this perspective argues that the "Islamization of Islam" is nowhere better visible than in the spatial ramifications of discourses that marginalize, exclude, or obfuscate both the multi-religious experiences in Islamic contexts and the continuous presence of Islam in European history.
\end{abstract}

KEY WORDS Religious diversity; Islam; Judaism; Christianity; inter-religious entanglement; religious tolerance; space; Middle East; Europe; Africa; America; Asia

\section{Introduction}

From a Muslim point of view, space travelling was still only an individual experience back in the 1980s-although 230 Arab guests watched the launch of the spaceship in Florida that took the first Arab to outer space. Prince Sulțān b. Salmān Āl Sacūd (b. 1956), member of the Saudi royal family and the second son of today's King Salmān b. 'Abd al-'Azīz (b. 1935), participated in Space Shuttle mission STS-51-G in 1985 and helped to deploy the second communications satellite for the multi-national Arabsat programme. A crew member woke him up when they passed over Saudi Arabia for 
the first time, and, looking from the upper deck window, the prince enjoyed seeing the Eastern province floating above him. During the seven days' mission, he gave a guided tour through the spaceship which was beamed back to Arab television viewers on earth. He was the first astronaut carrying a small Qur'ān and dates from Medinaas his special meal-to outer space. Together with the Qur'ān, the prince took with him his pilot's licence and a prayer dictated by his mother asking God to take care of the travellers, which he recited during take-off (Lawton and Moody 1986).

Some 20 years later, the scenery had changed. Before the first astronaut from Malaysia was rocketed to the International Space Station (ISS) in a joint programme with Russia (2007), 150 religious scholars gathered in Malaysia to discuss the challenges of Muslim life in zero gravity. The scholars not only approved of the mission's aim to study the secrets of the universe, but also discussed how often to pray, considering that ISS circled the earth 16 times in 24 hours, how to face Mecca in orbit, and how to perform prayers. The National Fatwa Council finally approved of the suggestions worked out in the "Guideline for Performing Ibadah at the International Space Station (ISS)" (Fischer 2008; Lewis 2013).

This example epitomizes the growing ambitions of Arab and Muslim-majority countries in conquering outer space (Koren 2018). 25 Arab satellites have been launched since 1985. The interest in space technology not only serves military and economic interests and provides national prestige, it also has a high symbolic "Islamic" value, as it invokes the "Golden Age" of Muslim astronomers in the thirteenth to fifteenth centuries (Koren 2018; Guessoum 2013). Arab interest in modern space technology, which can be traced back to the nineteenth century, has created a cosmopolitan scientific community transcending Arab and Western boundaries, as Determann (2018) has shown. When, in 2010, the Qatar Exoplanet Survey discovered an extrasolar planet 500 light years away, it was named "Qatar-1 b." The Emirates Mars Mission, composed of a team of 150 solely Emirati engineers, is preparing to launch a space orbiter named Amal ("Hope") in 2020 that is to reach Mars in 2021, just in time for the fiftieth anniversary of the foundation of the United Emirates. The data of the Mars mission will be provided to 200 universities and research institutes all over the globe, according to the mission statement. The Emirates have also announced a "Mars 2117 project," aiming to establish the first inhabitable human settlement on Mars within 100 years (Determann 2018; Koren 2018).

Outer space has not become a "Muslim space"; nor has exoplanet "Qatar-1 b" turned into a Muslim planet through these activities. However, the scientific endeavours mark outer space as a legitimate area of Muslim-majority countries' interests. Heavy investment, international and local experts' planning, religious scholars' approval, popular use of TV satellites, and the interest of the scientific community give credit 
and legitimacy to enterprises which produce a symbolic space that connects the great Muslim past to the future of humanity. What these examples show is that the social "production of space" (Lefebvre 1974) involves a variety of human actions, from investment, planning, and popular use to claims of legitimacy. These actions attribute not only cosmopolitan, political, economic, and technical dimensions to a certain space, but also religious, emotional, and symbolic value. In a sociological sense, space is not just there to be inhabited by human beings, but its different dimensions are produced, changed, or destroyed by them.

From this starting point, I question the usefulness of terms such as "Muslim space" and "Islamic world" as analytical categories and take issue with the ways in which an Islamic identity is often inscribed onto space and history, thus implying Muslim sameness, boundedness, and groupness that are also connected with medieval, sectarian, or anachronistic beliefs. While places appear to be sheer facts, "our conceptions of them (...) are cultural constructions born of particular moments in time" (Green 2014, 556). As analytical categories, geographical models should not only be designed to enable "the tracing of commonality or connectivity" (ibid.), but also to understand "dynamic and mutable spaces of interaction that enable patterns of dissemination, circulation, or competition among ideas no less than commodities" (ibid., 558). Following Brubaker's and Cooper's (2000) critique of "identity," a distinction between a category of analysis and practice is paramount. Common parlance about Muslim places and a Muslim's feeling of belonging to a certain space must be kept separate from a view that analyzes the practices of identifying and categorizing places and spaces; otherwise, the strong or soft ways of "identitarian theorizing" (Brubacker and Cooper 2000,7) expound either that Muslim spaces simply exist or that they are multiple, fragmented, and fluid, in short, arbitrarily constructed. Although the critique of "Orientalism" (Said 1978) has cast "serious doubts on the assumption that an Islamic entity can be regarded as a world apart from, or even opposed to, the 'western world'" (von Oppen 2001, 277), scholars have mainly taken issue with the strong way of identitarian thinking by showing "the making and unmaking" of the "internal boundaries" (ibid.) of Islam; they left the external boundaries as well as the problem of soft, fragmented identities mainly untouched. My proposal is that we should start seeing what is termed as Muslim spaces or an Islamic world as inherently diverse and affected, if not created, by circuits of global knowledge production.

Drawing on Tim Unwin's $(2000,26)$ insight in his critique of Lefebvre (1974) that "to say that our ideas about space are socially constructed is something very different from saying that space is socially constructed," my approach revolves around two concerns. First, I aim to show that the space of Islam has often been described as predominantly Islamic by historical actors and various observers, thus neglecting, 
ignoring, or suppressing its multi-religious character. As a way out of this impasse, I secondly propose a topological approach, arguing that the debates about Islam created a trans-religious and transcultural space in which ideas about Islam circulated. What today is usually categorized as "Islam" is thus part of a historically growing knowledge production that has been circulating between believers, unconventional believers, and adherents of other faiths for a long time. On the one hand, the internal diversity of Islam offers overlapping areas with other religions; on the other hand, the space of Islam expands beyond the territories under Muslim rule. Therefore, the following considerations do not simply aim to attract attention to the position of Christians and Jews under Muslim rule (e.g. Courbage and Fargues 1997; Pink 2016) or to the mutual perceptions between Muslims and adherents of other religions (e.g. Waardenburg 1999) or to the common history of Muslims, Christians, and Jews in the Middle East (Sharkey 2017; Conermann 2017). Rather, the focus is on the production and circulation of knowledge that created a transcultural space and turned Islam into a "mutable mobile" ${ }^{1}$ (van de Kamp 2016, 1 and 3f.).

The problem of the spatiality of Islam is embedded in a wider epistemological context. The so-called "renaissance of space" in the humanities and social sciences has generated partly ambivalent and contradictory effects, especially with respect to Islam (Dörfler 2010). The combination with other "turns" (Bachmann-Medick 2006) has often led to a "spatialization" of society, culture, or religion-and thus implicitly caused a reification of space and its congruence with society. The negative effect of this impasse was nowhere more obvious than in relation to things Islamic because the renaissance of space reconfirmed the outworn, yet still powerful idea of "cultural regions" and "cultural spheres" (Frobenius 1898; Braukämper 2005). Not only has the notorious example of Huntington's (1996) "clash of civilizations" used the lame differentiation between Western, Christian, and European versus Oriental, Islamic, and Arabic. Huntington's critics also regularly fall short of a productive alternative understanding of space when they are content with showing that his essentialist association of space with culture is merely the result of a discursive power that needs and produces the view about cultural and religious clashes (Dörfler 2010, 44). These critics' concern with the spatial manifestations of power indirectly affirms the congruence of space, culture, and power. Thus, the idea of an Islamic incommensurability with modernity, the West, or other religions often creates a vicious circle in which "re-orientalizing orientals" speak for authenticity and "orientalizing orientalists" for difference (Al-Azmeh 2003, 26). This vicious circle results in an "over-Islamizing of Islam" (Al-Azmeh 1996) and deeply affects the construction and perception of space.

$1 \quad$ I thank Simone Schleper for drawing my attention to this paper. 
An obvious example that comes to mind is how space and its boundaries are arguments in popular debates about Islam in Europe among Muslims and non-Muslims alike. On the one hand, critics of Islam in Europe nowadays believe they are witnessing an "Islamization of Europe," while some of their opponents, demanding inner-Islamic reform, wish for an "Europeanization of Islam" (Berger 2013). The spatial imaginary behind this debate is the question of whether Islam, or which kind of it, belongs to and fits in Europe (Hashas 2013). On the other hand, Muslim scholars also grapple with the inverse question of whether Muslim minorities in European societies should follow a special version of Islam, designed for a diasporic situation, the so-called figh al-aqallīyāt ("the jurisprudence of the [Muslim] minorities"). This expression came into being in the 1990s and has sparked controversial debates among Muslim scholars (Albrecht 2016). Dividing the social world into different spheres is a problematic use of the classical Muslim tripartition between the so-called territories of Islam, war, and treaty (dār al-islām, dār al-ḥarb, and dār al-'ahd). The European Council for Fatwa and Research, the most influential institution dedicated to producing norms for Muslims in Europe, constructs an image of otherness for countries outside dār al-islām, even for third- or fourth-generation Muslims who no longer have any ancestors in predominantly Muslim countries (ibid., 118). Other scholars vehemently oppose this kind of dividing the world and societies. Some of them question boundary drawing on the grounds that the Islamic creed is the same everywhere; others explicitly relocate dār al-islām in the West because its secular societies guarantee religious freedom (ibid., 117-127).

This example also brings to the fore that exclusively Muslim spaces are an exception-either because the Islamic character of a space is only one spatial dimension or because there exist opposing claims. Why, then, is the talk about Muslim space-with its "bloody borders," according to Huntington (1996, 254) - so pertinent? Why can an Arab grocery store be perceived as a Muslim place in Berlin but not in Cairo? Can Europe be regarded as a Muslim space in the same sense as the Middle East? Are European cities Muslim spaces and, if so, for whom? In other words, how do we-believers, observers, critics, or researchers-create and perceive, make and unmake Muslim spaces?

In order to approach these questions, it is necessary to unpack the dimensions involved in the production of space and Islam. Space obviously is a complex, dynamic, and relational configuration, not simply the geographical background of society (e.g. Löw 2001; Günzel 2017). Actors perceive, understand, and imagine space, while their own actions as well as their social relations produce space and give meanings to it. Rather generally put, elites invest in space, specialists design its future prospects, and people use it. Religiously marked space as well as religious architecture share in the material, cognitive, symbolic, and semiotic features that constitute social space (Knott 
2005; 2009). The production of religious space involves believers and non-believers with differing, if not opposing, interests and affects their perception, behaviour, devotion, and respect for such a space. A financial investment, purposeful planning, a material shape, a symbolic meaning attached to its architecture and an understanding of its symbols, expressed in a certain comportment, bring religious space into being, while at the same time regulating and controlling the flow of people and goods inside and around it. A speciality of religiously connoted space is that it can be impermanent, transnational and can change or lose its function. Religious space can be a playground for conflicting claims, but also for inter-religious sharing. Whether actors openly claim a space to be Christian, Muslim, or multi-religious, and whether they try to change its identity or leave it open, depends on the physical availability, symbolic importance, and forms of legitimacy at play (Weltecke 2012).

In early modern times, an understanding of "cultural geography" was not yet present; it came into being in the nineteenth century (Frobenius 1898; Braukämper 2005). The term "Islam" has also only come into popular use since the nineteenth century and stands for an academic convention with its own history; it is used to categorize a form of intra-religious diversity under one umbrella term and to distinguish it from other forms of intra-religious diversity. In the past, Muslim heresiographers would not have considered every branch of what researchers today call Islam "Islamic" (see van Ess 2011); Christian Europeans, who might not have considered themselves as Christian Europeans in the literal sense, did not even use the term "Islam" before 1697 in French and before 1818 in English (Tolan et al. 2012, 14f.), and most of them thought of Muhammad as a "Turkish prophet" and understood Mohammedanism as a "Christian heresy". Although the term "musulman" and "moslim" can be found in French and English sources from the sixteenth century onwards, neither peoples nor spaces were Islamized. The terms mostly used for Muslims referred to their ethnic belonging (like Arabs, Turks, Persians, or Moors) or were of Biblical origin (like Hagarenes, Ishmaelites, or Saracens) (ibid., 12-17). Ottoman travellers were often categorized as Orientals or Levantines, "which could designate any merchant from the east, including Greeks, Jews, Armenians, Maronites, Persians, Turks, or Arabs" (Krstić 2015, 685).

The following chapter tries to describe the space of Islam from a fresh perspective by carving out its multi-religious topology. Firstly, I give an overview of the terminology that is usually used to inscribe Islam onto space and history. I distinguish three approaches-geographical, cultural, and trans-local/national/regional-in the academe and highlight their underlying premises and theoretical difficulties. My criticism mainly aims at showing that these terms tend to homogenize existing differences with regard to places, peoples, and cultures. Secondly, I propose the concept of a multi-religious topology of Islam as an alternative for a different understanding of Islam and its 
location. The concept does not only mean that religious diversity and relationality are a permanent given of Islamic contexts; it also argues that the circulation of knowledge created a transcultural space of Islam. The multi-religious topology of Islam also involves actions and perceptions of non-Muslims and even circumstances in which Muslims were not personally present. As will be shown, the topology of Islam encompasses a global sphere, ranging from debates about Islam, violence, and tolerance in the ages of the Reformation and Enlightenment in Europe to debates about the treatment of Native Americans, religious freedom, and slavery in the Americas.

What is said here could most probably be said, with slight variations, about other religions as well and seems, in this respect, to verge on a platitude. However, the following remarks are not only directed against the "over-Islamization of Islam" (Al-Azmeh 1996), but also against a fetishism of geography and a one-dimensional understanding of spatialized-national, regional, cultural, or religious-entities. They speak back to the "epistemic violence" (Spivak 1993, 76) represented by "the remotely orchestrated, far-flung, and heterogeneous project" (ibid.) that constitutes the colonial subject as the Other and obliterates the trace of this Other. Following the anthropologist and historian Fernando Coronil $(1996,57)$, the overall aim of this chapter is to challenge

conceptions of the world, which (1) separate the world's components into bounded units; (2) disaggregate their relational histories; (3) turn difference into hierarchy; (4) naturalize these representations; and thus (5) intervene, however unwittingly, in the reproduction of existing asymmetrical power relations.

In this respect, the following considerations underline both the multi-religious experiences in Islamic contexts and the continuing presence of things Islamic in the European imaginary. Moreover, this chapter puts the existence of shared sacred places under Muslim rule-and the controversial discussion about this phenomenon

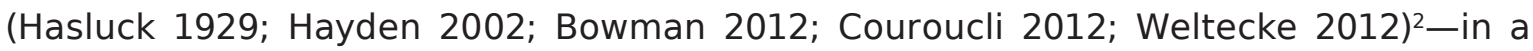
wider frame. By underlining differing spatial practices in multi-religious landscapes, I further challenge the trope of a violent Islam inimical of the religious Other. Instead, the history of Islam will be described as a continuous negotiation with religious diversity that was linked to inclusivist as well as exclusivist practices from its very beginning. ${ }^{3}$ The opposing practices can be better understood against the background of crossconnections, interdependencies, and shifting power relations between Muslims and non-Muslims in various places.

2 See also the introduction and Glenn Bowman's article in this volume.

3 For more details, see my article "Where Do the Multi-Religious Origins of Islam Lie? A Topological Approach to a Wicked Problem" in this volume. 


\section{Where and What is Muslim Space?}

In academic discourse, three different yet inter-related categories to locate Muslims in space can be distinguished. Firstly, (pseudo-)geographical terms like "Orient," "North Africa," "Middle East," "Central Asia," or "Southeast Asia" are often used to outline some of the "central" lands in which Islam has spread since its beginning and in subsequent centuries. Secondly, cultural-religious terms like "Islamic" and "Islamicate" civilization or "Muslim (Ottoman, Mughal) empire" are meant to designate the unity of Muslims, sometimes in far-flung lands, either in an idealistic sense (comparable to Muslim expressions like umma or dār al-islām) or in a political sense (like in the case of Indian Muslims' support for the Ottoman caliphate in the early twentieth century). Thirdly, different "trans-" perspectives-from "trans-local" to "trans-national" and "trans-regional" to "trans-cultural"-highlight Muslims' connections across boundaries. This last approach is a result of a growing unease with conventional area studies-an unease scholars in various fields have felt in the wake of globalisation and at the end of the Cold War since the 1990s (Mielke and Hornidge 2014). Whereas conventional Area Studies focused on fixed physical or cultural territories, demarcated by clear political or cultural borders, a "post-Area Studies perspective" questions these boundaries and understands spatiality not as a given but as shaped and re-shaped by human experience, action, and imagination. It looks at the transgression of boundaries, processes of entanglement, and the negotiation of space as well as at various forms of mobility, dynamism, and at networks (ibid., 18f.).

Each of these designations of Muslim space has its blind spots. Geographical and cultural-religious ascriptions designate space as a rather stable entity, mostly ignoring the contingency of the underlying terminology. The "trans-" perspectives, in contrast, focus on interconnectedness and "contact zones" (Pratt 1991) and tend to dissolve complex social, religious, economic, and political structures into channels, routes, and networks through which people, goods, and ideas flow, without being able to say much about the specific nature of the social structures behind these flows.

Geographical terms suffer the most from the limitations of a container perspective on space. They describe geological, economic, cultural, or religious characteristics of the areas under study as if they explained the existence of Muslims in these areas. In a recent handbook article, Escher (2016) deals with the "geography of the Islamic space," yet largely focuses on 28 countries of the MENACA region (Middle East, North Africa, and Central Asia) and their characteristic, "semi-arid" features. As this region comprises only half of all Muslims worldwide, he is well aware that the "Islamic space" could (or should?) also include Southeast Asia and Sub-Saharan Africa (ibid., 12, 17). However, these regions, as well as the existence of Muslims in Europe and America, are dealt 
with in separate chapters of the same handbook. This arrangement implicitly treats the MENACA region as the primordial Muslim space, whereas all other regions are only marked by the presence of Islam and Muslims "in" them, meaning that they obviously do not represent inherently Islamic spaces. The focus on an "Islamic geography" in the MENACA region allows elucidating some common features with regard to agriculture, nomadism, urban development, water policy, and "problematic natural resources," such as oil and gas (Escher 2016, 18-33); yet it necessarily remains unclear how the socio-economic features of this Islamic space can explain "the socio-political dynamics" (ibid., 33-40) and a "geography of violence" (ibid., 37-40) in this Islamic space. It seems questionable how the identified elements of and in the Islamic space are connected with each other, in how far these elements are historically connected to the emergence of Islam and its development, and how closely geography and religion are generally interrelated. Singling out 28 countries because of an arbitrary criterion-the historical depth of Muslim presence and the high Muslim percentage in the present-neither explains the presumed "Islamic" character of this area nor the spread of Islam beyond this area with its presumably characteristic features, from the existence of Tatars in Poland and the Baltic region for 500 years (e.g. Svanberg/Westerlund 2016) to the conversion of indigenous peoples in Australia and New Zeeland in more recent times (Onnudottir et al. 2012).

Even with regard to the MENACA category, the question arises which countries should be placed inside the category. Why is Pakistan included, but India-with numerically nearly as many Muslims as Pakistan-excluded? Why is the predominance of Muslims a criterion while Indonesia, the country with the most Muslims worldwide, is not part of the region? Why does Northern Africa belong to a region extending to Fergana Valley and is set apart from the rest of Africa while nearly half of the latter's population is Muslim? This separation proves that Islam in Africa is still perceived as being "rather peripheric" although "Muslims in Sub-Saharian Africa form one of the largest bodies of Islam worldwide, second only to the Indian subcontinent" (Loimeier $2009,287)$. The MENACA category also suggests that Islamic space and the MENACA area as a whole are somehow synonymous, in spite of various religious minorities, such as Christians of Eastern and Western denominations, Jews, Zoroastrians, Bahā'īs, or Yezīdīs.

To be sure, MENACA is not only an acronym used by scholars, but also by the United Nations (Escher 2016, 12; United Nations 2018). The five UN regional offices include and exclude Arab and Muslim countries in a somewhat arbitrary manner. The Economic and Social Commission for West Asia (ESCWA) encompasses 18 Arab countries in Asia and North Africa, but not Algeria, Morocco, Mauretania, Sudan, Djibouti, and the Comoros, all of which are members of the Arab League. These six states are part of the regional 
office of the African group (ECA), which also includes the other three Arabic states of North Africa (Libya, Tunisia, and Egypt). Turkey and Iran are part of the regional office for Asia and the Pacific region (ESCAP), which also includes the Central Asian and South Asian states with substantial Muslim populations and extends from Russia over China to New Zeeland. Israel is neither part of "West Asia" nor of "Asia and the Pacific", but is treated as part of the regional office for Europe (ECE), which also includes Central Asia (Kazakhstan, Kyrgyzstan, Tajikistan, Turkmenistan, and Uzbekistan). The only regional office that does not include any Muslim-majority state is the one for Latin America and the Caribbean (ECLAC). ${ }^{4}$

This allocation of contemporary Muslim-majority societies to different regions is far from clearly defined. Moreover, in the MENACA acronym lurks the pseudo-geographical term "Middle East" that brings with it a package of political, cultural, religious, and historical assumptions (see the discussion in Bonine et al. 2011). While other fields in academia are designated with more neutral terms, pertaining to continents-e.g. African or South Asian Studies-, this has not happened with "Middle East" studies, whose region is said to lay somewhere in between. The terminology remains a mirror of European interests and a relic of Euro-centric nomenclature (Khalidi 1998, 74). While its boundaries are unclear, a relation to Islam is suggested but not clearly expressed. Following Davison's (1960) recommendation to make the "damage-limiting best" (Green 2014,562$)$ out of this category, Green $(2014,557)$ has pointed at the possibility that scholars might agree on arbitrary limits of the "Middle East" and redefine the category "for each and every analysis". For the similar term "Near East"-a term mainly used in French and German-an "epistemological crisis" (Reinkowski 2017) has been diagnosed, especially with the mass migration over the Mediterranean Sea following the Arab revolts in 2011 . The region has come too close to many Europeans, since "near" originally meant close enough for Europeans to reach it, but far enough away from "them".

With regard to the formerly very prominent notion of the "Orient," the same problem of imprecision holds true, since the region has been perceived just as small as the "Near East," or as a synonym for Asia, or as including parts of Africa. Edward Said pointed out in the late 1970s already that the production of images of the "Orient"by connecting it to Islam, Arabs, violence, and promiscuity-was a "Western style for dominating, restructuring, and having authority over the Orient" (Said 1978, 3). Astonishingly enough, his-for the most part valid-critique, concerned with the de/ construction of the binary of Orient and Occident as it was, did not breathe a word

4 This office, however, promotes the Forum for East Asia-Latin America Cooperation (FEALAC), in which Indonesia, Brunei, and Malaysia are engaged, but no other Muslim-majority country from "East Asia." 
about the Ottoman Empire and its ambivalent position beyond this binary (Bryce 2013). For centuries, the Ottomans were present in Europe, had a vast number of Christian subjects, and could hardly be subsumed under the category of the "Orient," although they were certainly depicted as the "Other" in European discourses throughout the centuries (Konrad 2011). Thus, Said avoided making sense of the fact that the Ottoman Empire was deeply involved in the power game of European states for centuries and represented a third entity, situated beyond the simple dichotomies of Orient and Occident, Islam and Christianity.

With this example, we have come to the second category, cultural geography. It is controversial whether and for what epoch we can speak of a distinct Muslim, Islamic, or Islamicate civilization. Aydin (2017) has recently pointed out that the idea of the "Muslim world" was only coined in the nineteenth century by European colonialists and then adopted by Muslim elites to counter racism against Muslims. From the seventh to eighteenth centuries, the idea of Muslim solidarity practically proved "politically impotent" (Aydin 2017, 15), since the Muslim political experience was characterized by "multiplicity, contestation, and change, leaving the idea of the Muslim world to emerge later, alongside the later civilizational narrative of the West" (ibid.). In contrast to this argument, Ahmed (2016) tried to show that Islam in "the Balkans-to-Bengal complex" (ibid., 74) can be conceptualized as "the co-herence of contradictory norms in the lived 'religious' reality of Muslims" (ibid., 46; emphasis in the original). Thus, the differing ideas that Muslims expressed in philosophy, Sufism, poetry, art, and the celebration of wine consummation seemed to stand in stark contrast to Qur'ānic and Sharī'a prescriptions. That Ahmed takes "the unity in diversity" of the Islamic worldview and experience as his starting point makes it rather challenging to come up with a precise definition of Islam, yet he remarks that contradictory ideas and norms were a commonplace phenomenon in Islam from 1350 to 1850. For him, this "Balkansto-Bengal paradigm" marks "demographically, spatially, and temporally an (if not the) historically major paradigm of Islam" (ibid., 82; emphasis in original) before the European encroachment into Islamic lands in the nineteenth century. In a similar way, Abu-Lughod (1989) already spoke of a "world system" prior to European hegemony for the thirteenth and fourteenth centuries; in Lapidus's (1989) view, a "world system" of Muslim societies existed up to eighteenth century.

The attempt to determine an Islamic space and underline its historical importance is directly inter-connected with the much-debated question of where Islam stands in relation to world history (Abu-Lughod 1989; Lapidus 1989; Eaton 1993; Hodgson 1993; Voll 1994; Clarence-Smith 2007): How does Islam relate to the emergence of the modern world system? Can it be seen as a "world civilization" in its own right? When was it integrated into the European hegemonic global system, developing at some 
point after 1500 ? Reichmuth (2000), discussing the different approaches, shows how this debate is related to other theories and grand narratives, from Hodgson (1974) to Wallerstein (1980-1989) and Braudel (1979/80) to Frank (1998). These authors hold completely different views about Islam. Hodgson understands the Islamicate world as key mediator between Asia and Europe, Antiquity and Modernity; Wallerstein does not treat Islam as a socially, economically, or politically important unity; Braudel partially integrates Islam into his narrative in an ambivalent manner; and Frank subsumes Islam under the category of an Asian age in world history/economy. Therefore, Reichmuth $(2000,81 f$.) is sceptical whether it is adequate to speak of different interacting "world systems" and of a special "Islamic world system" in a cultural and economic sense. He remarks that Muslims' economic activities, at least since the seventeenth century, were too much entangled with South Asian and European spaces to make the expression of a coherent Islamic world economy meaningful. Even expanding religious networks, spanning several regions, are no indication for a cultural, discursive Islamic world system. Rather, giving up on the idea of a coherent system leaves room for multiple and contradictory relations, according to Reichmuth (ibid., 82).

Like the geo-political nomenclature, the geo-cultural terminology, which tries to ascribe a cultural (and economic) sphere to Muslim activities, suffers from the deficiencies of the container perspective. The cultural boundaries of a term like "Islamic civilization" are as unclear as the geo-political boundaries of the "Middle East." Not only does it homogenize cultural-religious internal differences when it calls a civilization "Islamic." It also has little to say about Muslim minorities with possibly different traditions outside of Muslim empires or Muslim-majority societies. From a cultural perspective, Muslims in peripheral Islamic areas in Africa, Asia, Europe, and the Americas dwell in the "wrong" places, similar to Muslims outside out of the geopolitically constructed MENACA region. In what sense are these Muslim minoritiessuch as the Moors in Sri Lanka, the Rohingya in Myanmar, or the Cham in Cambodiapart of "Islamic civilization" and not also, or even more so, of South Asian cultures? Is it not impossible to understand diverse local traditions from an exclusive Islamic point of view, such as the approximately 300-year-long tradition of women's mosques (qingzhen nusi) and their female religious leaders (nu ahong) among the Chinese Hui (Jaschok and Jingjun 2000), or the zār-cult in Ethiopia, Sudan, and Egypt, or the bori-spirit possession cult in Hausaland, and the East African pepo-cult (Loimeier 2013, 33)? A way out of this impasse seems to be the terminology of the "world of Islam" or an "Islamic world," which is, for example, used in the possibly most comprehensive encyclopaedia about Muslims around the globe to date (Esposito 2009). In its claim to be comprehensive, it includes entries even about the tiniest Muslim minorities. However, the problem that arises from this perspective is that the "Islamic world" corresponds to the globe. Not 
only do Muslim-majority societies make up the 'Islamic world', but Muslim minorities in secular societies or regions with different hegemonic cultural or religious traditions are also part of it. In what sense can these diverse spaces be subsumed under the heading of an "Islamic world"?

A different way of looking at blurry, porous boundaries are trans-national, transregional, trans-cultural, and trans-local perspectives that are interested in migration, mobility, and the interconnectedness of political, economic, cultural, and religious phenomena (Budde et al. 2006; Welsch 2017; Freitag and von Oppen 2010; Mielke and Hornidge 2014). In these approaches, spaces such as the Mediterranean, the Indian Ocean, the Black Sea, the Silk Roads (Frankopan 2015), and the trans-Saharan trade routes have drawn new scholarly attention in recent years because they are placed at the crossroads of continents, "civilizations," and religions. Green (2014) has proposed to "disaggregate and enlarge" the Middle East into three intersecting arenas: a Mediterranean arena, an inner Asian arena, and an Indian Ocean arena. Although these arenas also run the risk of being reduced to a container understanding of space, the new scholarship indulges in them to highlight forms of exchange across boundaries. Already in the monumental work on the Geniza documents, Goitein (1967-1988) portrayed Jewish communities of the Arab world as an integral part of a "Mediterranean Society." Putting Islam at centre stage also helps to explain how, under Muslim rule, technological toolkits from the Romans, Persians, Indians, and Chinese-such as water management, writing and book technology, as well as mathematical expertise-were acquired and refined, and helped to bring about (European) modernity. The ensuing decline of the formerly dynamic region between 1500 and 1800 is then explained not by drawing on cultural (Islamic) factors but from an "ecohistorical perspective," which underlines the limitations in man power and natural resources compared to other regions of Eurasia (Burke III 2009 and 2012).

The interconnectedness of various spaces can be put to work in different ways. Regarding the Mediterranean region, some scholars underline its distinctiveness and connectivity for more than two millennia or since pre-history (Horden and Purcell 2000; Abulafia 2011); others stress the multi-directionality of migrations from and to different shores and rather speak of "Mediterraneans" (Clancy-Smith 2010); some question whether there is a distinct and coherent history of the Mediterranean and rather argue for a "coherent eastern Mediterranean world" (Holmes 2012, 13f., 23-25); still others focus on the mutual impact between the French Revolution, the Ottomans, and the southern rim of the Mediterranean basin (Lorcin and Shepard 2016, Firges 2017). Similarly, a focus on the Indian Ocean tries to capture the trans-local, multi-directional flows of people, goods, and ideas around the rim of the ocean and place them in Islamic as well as global history (Conermann 1998; Deutsch and Reinwald 2002; Freitag 2003; 
Freitag and von Oppen 2010). This approach can also be applied to Ottoman relations to South Africa (Kavas 2007) or to Islamic transatlantic contexts in Brazil and South Africa (Gebauer and Husseini de Araújo 2012). Focussing on techniques of mobilisation or on network analysis can further help to explain the different ways in which political Shiism has recently spread in Cambodia and Venezuela (Bruckmayr 2018), how actors create "transnational Shia communal spaces" and networks in London (Scharbrodt 2018), how Salafism was located among the Oromo Muslims of Ethiopia (Østebø 2012), and why the recruitment of the self-proclaimed "Islamic State in Iraq and Syria" has been rather successful in Trinidad (Graham-Harrison and Surtees 2018).

What transpires from the three-geographical, cultural-economic, and transregional-perspectives is that a "Muslim world" is envisioned by academic researchers with different agendas. The mutability of geographical models not only reveals the varying interconnections of the same spaces; it also shows that different spatial models "suit different questions and methodologies, not to mention different periods" (Green 2014 , 557). The geo-political construction of Muslim space can easily exclude half of all Muslims and locate them somewhere in an ill-defined outside. A cultural geography that is concerned with locating bygone Islamic civilizations can similarly fall short of taking into account the experiences of Muslims beyond the borders of former empires and locate them in ill-defined diasporas. It further has little sense for the facts that (1) "Islamic civilization was a big house" (Sharkey 2017, 16), produced "not only by and for Muslims" (ibid.) but also by non-Muslims, (2) that "Muslim, Christian, and Jewish populations in the Middle East historically exhibited considerable internal diversity" (ibid.), and (3) that Middle Eastern societies were never monolithic and static (ibid., 17). Trans-regional and trans-cultural perspectives that are more interested in the interconnectedness of places and peoples than in carving out a distinct Muslim space implicitly tend to make the "in between" position of Islam their raison d'être. These kinds of studies can foster forms of fragmentation with regard to Islam. When Islam is seen as entangled in trans-local/national/regional contacts, the container of a Muslim space is dissolved into contact zones; yet these zones appear to be rather exceptional in relation to a traditional understanding of Islam. For example, the historiography of the Ottoman Empire already suffers from a fragmentary character along regional, national, ethnical, tribal, or epochal lines and faces "difficulties in bringing together the work of historians from different local realities" (Lafi 2014, 246). Therefore, the long history of the Ottoman Empire, with its European and extra-European parts, finds different expressions in national, comparative, and global historiographies; its integration into the periodization and research interests of European historiography poses a challenge that is far from solved (Helmedach et al. 2013). 
It is not the intention of the preceding discussion to proclaim the relativity of space according to differing agendas. Rather, the aim is to underline the relational nature of spaces that are termed as "Muslim spaces." Islamic communities in Western cities are not only incorporated in a changing material and sociological landscape; they are also grounded in trans-local and trans-national connections and reflect personal as well as gendered experiences, all of which produce changing modes of visibility, othering, resistance, adaption, and self-perception (Bendixsen 2013). In a mobile world, religious and confessional identities "cannot be taken as a deep-rooted social reality but as having been actively produced, and reproduced in an on-going process" (Peleikis 2001, 400). Migration can directly affect and change the ritual practices, performance, and embodiment of religious identities (Langer et al. 2005). The re-negotiation of religious identities can take place "on a translocal and transnational scale in the interaction between local, regional, and national actors" (Peleikis 2001, 400), thus between processes that tend towards a "territorialisation of identities" in the home country and a "de-territorialised social space" that binds a physically dispersed community together, as Peleikis (2001) shows with regard to groups from multi-confessional Lebanon. This paradox effect is also visible in the heterogeneous Shiite communities in Germany, "highly diversified in terms of their linguistic, national and ethnic backgrounds and ritual practice" (Langer and Weineck 2017, 216), as they show considerable differences in the representation and reproduction of their faith (ibid.). The argument, developed from here in the rest of this paper is that a topology of Islam must grasp this dynamism and diversity, which means that the sense of what it means to ascribe "Islamicity" to a community and its location is subject to ongoing negotiations between its members as well as other Muslims and non-Muslims.

\section{Towards a Multi-Religious Topology of Islam}

The attempt to carve out the multi-religious topology of Islam rests on the idea that religious diversity has a direct imprint on spatial practices and vice versa. The following description connects the multi-religious dynamism that is visible in (changing) Muslim practices, norms, and institutions with historical inter-religious encounters and mutual perceptions as well as with non-Muslim discursive uses of Islam, the European knowledge production and transcultural circulation of ideas about Islam. The term "topology" describes this relational understanding of space and differs fundamentally from "topography," in the sense that the latter represents a mere physical location (Günzel 2017, 110-140). Topography rests on a container understanding of space, according to which two objects cannot be in the same place at the same moment; with 
this view, places or people residing in them can also be ascribed a singular identity of cultural, national, or religious provenience. In contrast, the topology of a location can change over time because of its relational and dynamical nature, even if its topography stays the same. For example, the perception of the same place changes in times of war and of peace (ibid., 127). In the same way, different perspectives and practices are connected with places and spaces shared by members of different faiths. Perspectivity and spatiality also apply to institutions that facilitate religious encounters and boundary-drawing. Thus, the institution of the dhimma, a contract of protection (and submission) of non-Muslims under Islamic law, went hand in hand with differing practices, depending on time and place; historically applied to a growing number of religious groups, it could even include simultaneous forms of tolerance and intolerance (Noth 1978). The same ambivalence holds true for the treatment of non-Muslim groups under the so-called Ottoman millet system, which was far from a comprehensive system prior to the eighteenth century (Masters 2001), but became increasingly differentiated in the nineteenth century and encompassed seventeen different confessions prior to World War I (Pink 2016, 495). Instead of focusing on the "status" of dhimmi minorities under Muslim rule, an alternative view is to trace the non-Muslim "responses" to Muslim rule, which opens up a "matrix of interfaith relationships" (Simonsohn 2017, 362). As soon as non-Muslims responded in favour of the possibility of participating in Islamic institutions, they blurred traditional communal boundaries and triggered a spectrum of further "responses from various parts within non-Muslim communities" (ibid., 363) but also Muslim reactions. Regarding the question of how the "Ottomanization" of newly conquered lands worked, Hadjikyriacou (2016a; 2016b) suggests focusing on multi-layered encounters in "contact zones" (Pratt 1991) and leaving behind statecentric approaches as well as the periphery-centre binary. The case of Cyprus from the seventeenth to nineteenth centuries reveals that-while there was "no inhibition about empowering non-Muslim locals" (Hadjikyriacou 2016a, 250)-the rise and fall of individual actors of Christian background was characterized by fluid confessional boundaries as well as inter-Christian conflicts, but also, more generally, by social dynamism as well political instability (Hadjikyriacou 2016a; 2016b).

A focus on multi-religious dynamism also helps to grasp the mutual perceptions that circulated between Muslims, unconventional Muslims, and non-Muslims. In this respect, it is necessary to think together the "internal" diversity of Islam and the "external" religious diversity in an Islamic environment, which seems to be rather challenging for scholars of religious and Islamic studies; they often take refuge in the problematic concepts of "orthodoxy and heterodoxy"5 (e.g. Langer and Simon 2008;

5 As there are no equivalent expressions in Arabic, many scholars denounce the terms as Eurocentric interpretative categories; yet as Langer and Simon $(2008,274)$ state, "even those who find the 
Dressler 2010). On the one hand, tropes from different religious traditions often appear to be intermingled and integrated into one communicative unity, which does not allow clearly distinguishing between Jewish, Christian, and Muslim elements, especially in the studies of Qur'ān and early Islam-in spite of (later) differences. ${ }^{6}$ On the other hand, Sunnī, Shī'ī, and Șūfī expressions of Islam and its regional, popular, and legal variants ${ }^{7}$ are sometimes so divergent and ridden with conflict that it also seems challenging to understand them as one religious tradition-even more so if we consider highly non-conformist groups that developed in an Islamic environment, such as Alawites (Nușayrīs), Durūz, Yezīdīs, Ahl-e Ḥaqq, Sikhs, Bahā'īs, and Aḥmadīs. The meaning of Islam has been permanently re-negotiated by a variety of social and religious groups, some of whom were considered Muslim by their co-religionists, while others were seen as dubious or even un-Islamic. When we start treating "Islam as an ever-changing set of arguments rather than a panoply of beliefs and practices" (Bashir 2018, 25), processes of negotiation about Islam also include decidedly non-Muslim groups who shared a common space with Muslims. As Waardenburg (2004) has shown, Muslim authors often treated Islamic sects and non-Muslim religions together in heresiographic works-with changing classifications. ${ }^{8}$ Terms such as milla or firqa, although used inconsistently, were applied to Muslim as well as to non-Muslim groups. In his Kitāb ta'rīkh al-Hind, alBīrūnī (d. 1048) not only gave a comprehensive insight into Hindu practices, folklore, cosmology, religion, and philosophy, but also compared them to existing Șūfī practices to make them understandable to his readers in spite of fundamental differences (ibid., 228).

Thinking about the multi-religious topology of Islam therefore involves rethinking how the very idea of Islam has been made, unmade, and remade but also materialized, manipulated, and stylized since its early years. In this respect, a main assumption is that religious flows are not unidirectional, emanating from a centre to the peripheries, but that a polycentric cartography of the sacred is shaped by pilgrims, scholars, travellers, and tourists through knowledge production, mobility, and different media.

term problematic, or declare its use inappropriate continue to apply it. Sometimes orthodoxy is avoided but tacitly implied while heterodoxy is openly addressed. As an indication of its somewhat questionable status in an Islamic context it is a common practice to put it in quotation marks."

6 This is further elaborated in my article "The Location of Religious Diversity at the Origins of Islam: A Topological Approach to a Wicked Problem" in this volume.

7 Scholars of Islamic studies not only differentiate between an Arab, Persian, Turkish, Indian, Indonesian, African (etc.), and European Islam but also between "orthopraxy" and "folk Islam" and the different, traditional legal schools.

8 Waardenburg discusses Ibn Ḥazm's (d. 1064) Kitāb al-fiṣal fí l-milal wa-l-ahwā' wa-l-nihal, Aḥmad Sharastānī's (d. 1153) Kitāb al-milal wa-l-nihal, and Abū Ma'ālī's Kitāb bayān al-adyān (1092). For greater detail on Muslim heresiography, see van Ess 2011. 
The topological focus on "exchange" and "circulation" brings to the fore that practices, objects, and ideas "transform in the course of their displacement and become 'mutable mobiles'" (van de Kamp 2016, 4). Drawing on this consideration, I suggest that there is not one Islamic form but multiple ones, and that processes of translation, addition, and appropriation "take different shapes but coexist in one particular space" (ibid., 5), especially when they come into contact with a multiplicity of other religious practices, ideas, and objects. Sketching historical examples in various settings will demonstrate how the polycentric dynamism of Islam, its expansion in space, and its encounter with various "Others" are inter-connected.

The history of the expansion of Islam is marked by attacks, retreats, losses, and re-conquests as well as by movements of religious renewal that emerged from different places and involved different tribal, ethnic, and religious groups. Although the emerging multi-religious topology of Islam marked the co-existence of a vast variety of religious "Others," it did not necessarily equate with a particular Muslim tolerance for the plurality of understandings of Islam or for a pluralist society, as already mentioned. A peculiar story tells how Muslim pressure forced the so-called "pagans" of Harrān-a strategically important town ${ }^{9}$ close to today's Şanlıurfa, on the border between Turkey and Syria-to become "people of the book" (ahl al-kitāb). ${ }^{10}$ According to a Muslim source, caliph Ma'mūn (ruled 813-833) tried to force the Harrānians to convert to Islam or at least adhere to a book religion. Under this pressure, they claimed to be "Ṣābi'ūn," a name of unclear origins for an undetermined group that was mentioned in the Qur'ān $(2: 62,5: 69 ; 22: 17)$ alongside Jews and Christians as "believers" and that, therefore, had the right to be treated as "people of the book." Although it is unclear whether the story is true or whether Șābi'un had already lived in the region prior to the reported event (Green 1992, 106), reading the source suggests two points: First, the boundaries between what was termed "paganism" and "religion" were fluid at that time. Second, acceptable religiosity was created by an interaction between a Muslim ruler's demand and the non-Muslims' smart response.

Historically, non-Arabs did not become Muslims overnight after the Arab conquests of the early centuries, and when they converted, they were obliged to enter into a relationship with an Arab patron and remained second-class Muslims (Crone 1991). For quite some time, a rather tiny ruling Muslim minority was confronted with a non-Muslim majority in the lands under Muslim control. From the sparse data available, Bulliet

9 The inhabitants played a vital role in the transmission of Greek philosophy and science. The Umayyads favoured the town and transferred a school of medicine from Alexandria to Harrān; caliph Marwān II (ruled 744-750) even made Harrān his capital in 745 (Bosworth 2003).

10 According to Al-Azmeh $(2014,183)$, the inhabitants managed to adhere to their pagan cult well into the tenth century, in spite of Christian and Muslim disapproval. 
(1979) has concluded, based on a statistical evaluation of biographical dictionaries, that conversions might have taken place in different regions with different speed and that it sometimes may have taken several centuries before the population in the conquered lands adopted Islam. Given this approach, roughly half of the population in Egypt might have considered themselves Muslims 300 years after the Muslims' conquest, while by the thirteenth century, the share may have risen to 90 percent (ibid., 92-113). Kafadar $(1995,76)$ describes the people of Anatolia and South Eastern Europe up to the fifteenth century as "metadox"- "a state of being beyond doxies, a combination of being dox-naïve and not being doxy-minded, as well as the absence of a state that was interested in rigorously defining and strictly enforcing an orthodoxy." Individual Jewish and Christian subjects of Muslim empires were able to hold high ranks in the administrations in several instances; although they were excluded from the military service, ${ }^{11}$ they could pursue their interests in trade, money lending, medicine, the sciences, and arts and craft, often without restrictions and alongside Muslims (Pink 2016, 493).

Irrespective of the sack of Baghdad (1258), the Mongols' conquests helped to spread Islam to new spaces between China, Central Asia, India, and today's Russia and Poland. The Mongols' advance produced a common space of interaction, imagination, and destruction and intensified the trans-regional traffic of goods, travellers, and refugees, also creating "a single disease zone" (Jackson 2017, 382; 405-408) which caused the spread of the Black Death between China and Europe in the mid-fourteenth century. Chingis Khan (d. 1227), recognizing "the disruptive potential of competing religions," decreed absolute religious freedom-"probably the first law of its kind anywhere in the world"-and exempted religious institutions from taxation (Weatherford 2004, 69). The conversion of Ghazan Khan in 1295 and other Ilkhanite rulers to Islam without privileging their new faith ${ }^{12}$ had repercussions on Muslims within and beyond the Mongolian empires and changed the organization of things Islamic in a political, social, cultural, and religious sense (Jackson 2017).

In the Ottoman Empire, Christians could be long-distance merchants, slaves, subjects, or vassals, and their respective social positions were based on a complex mosaic of regulations throughout the centuries. The privileged, extraterritorial status

11 The first serious attempt to draw Christians into the army happened in the Ottoman Empire in 1835, but compulsory service for non-Muslims was only introduced formally in 1856 and practically in 1909 (Zürcher 1998; Hacısalihoğlu 2007).

12 Ghazan Khan, for example, forged alliances with the crusaders against the Mamluks, subdued religious upheavals caused by a Muslim Mongolian ally, who supported the persecution of Christians and Buddhists, and made the Jewish convert Rashīd al-Dīn al-Hamdhānī a vizier (executed by his successor in 1318). 
of European merchants was regulated by so-called Capitulations, bilateral agreements between the Ottoman Empire and its European counterparts; such agreements, through which European merchants fell under foreign jurisdiction and evaded local taxes, were signed with the republics of Genova, Venice, Florence, and Naples as early as the fourteenth century, and later also with France, England, and the Dutch Republic; they remained in place until the twentieth century (Schölch 1975). On the other hand, Christians, caught in enemy territories or on the peripheries of the empire, were enslaved and served in many sectors of Ottoman society. According to Zilfi $(2009,531)$, slaves and former slaves made up a fifth of Istanbul's population in the sixteenth century, when Istanbul was the largest city in Europe and West Asia. As slave-ownership was associated with high social status, non-Muslims were discouraged from holding slaves, yet Christian and Jewish slave owners could be found "well into the 19th century" (ibid.). Christian boys from lands under Ottoman rule were taken from their families through devşirme (the child levy system) until the early eighteenth century; they were taught the Ottoman language and culture, converted to Islam, and trained as Janissaries (yeni çeri, "new soldiers"), which were established in the 1380s and existed until 1826 (see Ágoston 2009). As the elite corps of the sultans, or kapıkulu ("slaves of the Porte"), they enjoyed many privileges, were paid for their service, and could acquire a prominent status in administration and society; since the seventeenth century, they were also allowed to engage in trade and craftsmanship. Muslims and Turks were initially excluded from devşirme to avoid the development of a hereditary military aristocracy - a practice which only changed in the seventeenth century (ibid.). Enslaved girls and women of Christian and Jewish faith and of different ethnic origins also formed a continuous part of the sultans' harem; many of them also gave birth to children. As sultan's mother (wālidat sulțān), they not only enjoyed authority inside the Imperial Harem, but also seized political power, especially in the sixteenth and seventeenth centuries (Peirce 1993). ${ }^{13}$ Non-Muslim European visitors found the porous boundaries between the free and the enslaved as well as the social mobility of slaves "most striking and foreign to the aristocratic governance of their own countries" (Zilfi 2009, 532). At the same time, Christian rulers from Europe could be Ottoman allies,

13 Famous examples for this are Khürrem Sulțān, known as Roxelana (d. 1558), and Kösem Mahpeyker Sulțān (d. 1651). Roxelana was captured by the Crimean Tatars in Ruthenia and sold to Istanbul, where she rose from a slave girl to the favourite concubine and wife of Suleiman the Magnificant (d. 1566). Kösem, of Greek origin and the daughter of an orthodox priest, was sold by the Bosnian governor to the harem of Sultan Ahmad I (d. 1617), whose wife she became. After his death, she seized power during three periods of time, acting on behalf of two of her sons and a grandson. Both Roxelana and Kösem met a violent death after their fall from power. 
vassals, or enemies, just as other Muslim rulers could be considered opponents, rivals, or allies (Gürkan 2010). ${ }^{14}$

In spite of the dhimma institution, there were recurrent cycles of pressure against and laxness regarding non-Muslims throughout the centuries. Under the Ottoman Sultan Mehmed IV (d. 1693), military conquest and religious conversion were directly linked with each other; his war strategy aimed not only at converting individual Christians and Jews, but also at Islamizing the landscape by turning churches and synagogues into mosques (Baer 2008). There were also several documented attempts to forcefully convert Jews to Islam, for example in Andalusia and the Maghreb under Almohad (al-Muwaḥhidūn) rule ${ }^{15}$ in the twelfth century, or in Persia under Safawid rule in the seventeenth century as well as under Qajar rule in the nineteenth century (Reinkowski 2013, 88-90). Although rulers and authorities were well aware that forced conversion fostered techniques of dissimulation, they seem to have turned a blind eye and accepted them, not to mention that Jewish rabbis recommended them. Mōshe $b$. Maimūn, better known as Maimonides (d. 1204), pleaded for outer conversion when faced with the choice between emigration or death and emigration was impossible (Boušek 2011). In his correspondence, especially in his Epistle to Yemen (1172) in support of the Yemeni Jews, who seem to have faced persecutions at that time, Maimonides bitterly complained that the harsh treatment by the Arabs was unprecedented even in Jewish history: "Never did a nation molest, degrade, debase, and hate us as much as they" (quoted ibid., 50). It is controversial whether Maimonides himself was forced, under Almohad pressure, to pronounce the shahāda (Islamic creed) before he left Andalusia for Egypt (ibid., 54-59), where he was appointed by the Ayyubids as the nagid (religious leader) of the Jewish community. Two Arabic sources even tell the story that he was accused of apostasy (ridda) by a jurist in Egypt who had known him as a Muslim in Andalusia; according to the sources, the charge was dismissed by the judge at the Ayyubid court on the basis that a forced conversion was invalid and could therefore not fulfil the criteria of apostasy (ibid., 58f.).

With regard to the Christians of European regions, Muslim perceptions since the seventh century followed neither a single pattern of superiority and hostility nor a

14 For example, in the Battle of Ankara (1402) against Timur's Mongols, Christian vassals from Serbia and Albania fought bravely and loyally on the Ottoman side, while Black Tatar and Turkmen troops changed sides and joined the Muslim Mongol leader's multi-ethnic forces. During the Battle of Vienna (1683), not only did the Ottoman troops include confederates from Wallachia, Upper Hungary, Moldavia, and Transylvania, but Crimean Tatars were also on the Ottoman side, while Lipka Tatars fought with the Polish relief forces.

15 For a nuanced picture of the Almohad rulers, who were formerly often depicted as fanatics, and their treatment of Jews, see volume 2 (2) of the Journal of Medieval Iberian Studies, especially the articles by Bennison/Gallego (2010), Bennison (2010), and Corcos (2010). 
terminological consensus about the names, titles, toponyms, and ethnonyms applied to a broad range of peoples of the northern hemisphere (König 2010; Bennison 2007, 165-173). While the Qur'ān already used an intricate terminology for Christians, further inconsistencies resulted from the complex practical relations with various Christian groups. In spite of numerous refutations of Christianity by Muslim theologians, a combined religious and geographical definition of "Latin Christianity" as an entity in its own right "does not seem to have existed" (König 2010, 32) until early modern times. Different sources classified the pope as "the damned one," the "caliph of the Franks," or the "friend of kings and sultans" (ibid., 39). This inconsistency attests to the fact "that Muslim scholars were not in agreement on how to classify an institution whose activities had never been confined to the European continent" (ibid., 42). Apart from this, the land-conquering Umayyad and 'Abbasid rulers viewed themselves as heirs of previous civilizations, including Greece, Rome, Byzantium, and Persia, and therefore had no qualms about incorporating their predecessors' knowledge and techniques into their own administration (e.g. Husayn 2012; Kaplony 2016). Some Ottoman sultans "aspired to and perhaps even believed themselves to be Roman Caesars, Kayser-i Rum" (Gürkan 2010, 15). The conqueror of Constantinople, Mehmed II (d. 1481), considered himself the "true heir to the Roman throne" and "did not hesitate to consider the propaganda that linked the Ottoman and the Komnenos dynasties" (ibid.). He understood himself as "the Islamic fulfiller" of Roman imperial power rather than its destroyer, "curious about and responsive to Italian and wider European culture" (Abulafia 2012, 291). ${ }^{16}$

As early as the eighth century CE, the Umayyads conquering Andalusia laid claim to Roman heritage; some of them even claimed descent from the Visigoths (Bennison 2007, 162). According to the sources, there seems to be evidence of "agreements and alliances between Muslim commanders and Visigothic notables" (ibid.) during the early conquest of Spain, which was accompanied by cases of intermarriage. The symbiosis between Visigothic and Umayyad styles was not only expressed in the adaption of local customs, but also in architecture and urban planning (ibid., 164f.). This kind of co-operation on several levels stands in contrast to the myth of the reconquista, which began to emerge as early as the ninth century at the Asturian court (ibid., 161). With regard to Christian slaves and captives from the North, a common ethnic term for men was saqlabì ("Slav"), while women were often called rūmiyya ("Christian") in Andalusia. In reality, both men and women could hail from anywhere between the domains of the Carolingians and the Volga, since there existed various commercial routes with

16 His claim was rivalled by opponents like Alfonso the Magnanimous of Aragon (d. 1458), who tried to defend the Balkans, the Adriatic, and the eastern Mediterranean against the Turks; a romanized Spaniard, Alfonso saw himself as "the spiritual and in a sense the physical heir to Trajan and Hadrian, Roman emperors of Spanish origin" (Gürkan 2010, 15). 
merchants of diverse religious and ethnic background involved (ibid., 172). The majority of captured women seems to have come from northern Iberia and entered elite households as wives, concubines, and domestic servants, and continued on speaking their native languages. Because of this, the Muslim elite even feared that romance was ousting Arabic in the families, since "the majority of the mothers of amirs and caliphs were of northern origin" (ibid., 173); paradoxically, Christians in Andalusia were, at the same time, concerned that the spread of Arabic as a literary, scientific, and public language would replace Latin.

A peculiar case of entanglement between Muslims and the local population is the Arab, or possibly Berber, outpost called "Fraxinetum" in Latin sources (arab. Farakhshanīț) that existed between the end of the ninth and the end of tenth centuries in the Provence near today's St. Tropez (Versteegh 1990; Vogel 2016), independent or semi-independent from Cordoba. ${ }^{17}$ The sources attest that after their defeat, not all of the "Saracens" were killed, but some of them stayed in the region and converted (Versteegh 1990; Vogel 2016). Fraxinetum represents an early example of a landscape in which a multiplicity of actors with different identities, loyalties, and interests interacted. Like Fraxinetum, Andalusia as well as the Umayyad, 'Abbāsid, and Fatimid empires in the Eastern Mediterranean were connected with northern Europe via trade routes through which slaves (șaqāliba) from Middle and Eastern Europe were traded for dirhams up to the eleventh century (e.g. Jankowiak 2017). The import of goods and spices from the centers of Muslim commerce profoundly changed the emerging European economy-a transformation that was not only visible in the goods that travelled, but also in the movements of pilgrims, warriors, slaves, merchants, diplomats, and emissaries (McCormick 2001). This trans-cultural mobility across the Mediterranean found its continuation in early modern times, when European states had Muslim subjects, renegades, and allies, just as the Ottoman and North African states had Christian and European ones (see e.g. Davis 2006; Konrad 2010; Krstić 2011; Graf 2017).

For the global circuit of knowledge production about Islam, it is therefore necessary to have a look at such inter-connections between the various Muslim and non-Muslim contexts. Before I turn to this subject, let us first of all consider how three examples that seem to contradict the multi-religious topology of Islam fit into these considerations.

17 From here, the Berbers controlled trade routes and alpine passes and raided the region between today's Italy and Switzerland, but also participated in the trans-regional slave trade-actions that were similar to those practiced by other non-Muslim local and regional powers, with which the Berbers rivalled. Although the sources written by clerics paint a rather negative image of the "Saracens," the religious difference may have only represented one factor among others and prevented neither co-operation between Muslims and their non-Muslim peers nor intermarriage (König 2017). 
Following this, I will then examine how Muslims and non-Muslims understood and debated the position of Jews and Șūfīs-as "inside outsiders"-under Muslim rule. In a further step, I describe how the trope of Islam as an anti-Trinitarian Christian heresy circulated throughout history and was connected with debates about religious violence and tolerance. Then, I shed light on the European knowledge production on Arabic philosophy and Islam by way of translation work.

\section{Three Examples of Seemingly Non-Diverse Spaces}

A famous tradition expressing and denigrating religious diversity at the same time is Muhammad's hadith about the sects (firaq) that stipulates, in different versions, that Islam will be divided into 73 sects in contrast to the 71 Jewish and 72 Christian groups, and that only one, the 73rd group, will be saved from hellfire (for background information, see van Ess 2011, 3-64). Plurality inside Islam and religious diversity-as also noted in Qur'ān 5:4818-are therefore a given in Islamic tradition. Yet they do not directly express tolerance, since the claim to one religious truth is not dropped but postponed and subjected to a practical test. In this context, it is necessary to underline, as van Ess $(2011,1298)$ has done with reference to Islamic heresiography, that the terminology of "orthodoxy" and "heterodoxy" has no clear-cut analogy in Islam due to a lacking central authority for questions of faith. This does not mean that there were no processes of denouncing, centralization, and confessionalization or attempts to define dogmas; on the contrary, there were ongoing struggles for the dominant position ${ }^{19}$ which often, but not in every case, rested on the trials and tribulations of political luck and servitude. ${ }^{20}$ In the face of the difficulty to ascertain which Islamic group was the saved one, the Șūfi Yunus Emre (d. 1321) voiced the idea that "you should kiss the feet of the 72 sects" (van Ess 2011, 3). His praise for plurality implicitly results from the

18 "We have sent down to you the Book with the truth, confirming what was before it of the Book and as a guardian over it. (...) For each [community] among you We had appointed a code [of law] and a path, and had Allah wished He would have made you one community [nation], but [His purposes required] that He should test you in respect to what He has given you. So take the lead in all good works. To Allah shall be the return of you all, whereat He will inform you concerning that about which you used to differ."

19 Langer and Simon $(2008,281)$ argue that a claim to orthodoxy "must meet certain requirements, such as body of texts, a genealogy, flexibility, comprehensibility, the ability to integrate deviation, to manage boundaries, and produce consent."

20 A famous example to define orthodoxy is the so-called mihna ("ordeal") period (833-848 CE), when the caliph proclaimed the Mu'tazilite doctrine of "the createdness of the Qur'an" (see e.g. Nawas 1994). 
failure to draw a clear line that would separate the 73th group from all the others. The attempt and failure to draw a separating line thus marks a spatial practice that divides and connects different groups at the same time.

Historically, the way of negotiating this separating line could turn fatal, accept ambiguity, or lead to a schism. In rare circumstances, the interaction between Sunni authorities and the rulers' quest for legitimacy could lead to the execution of respected scholars, as was, for example, the case with the Persian Șūfĩ scholar Shihāb al-Dīn alSuhrawardī (d. ca. 1191/92) and the Arab Shī'î scholar Zayn al-Dīn al-'Āmilī (d. 1558). Although the reports at hand about the events that culminated in these executions appear confusing and contradictory, it seems obvious that the scholars were put to death under the charge of holding unorthodox or heretical views (zandaqa) (Marcotte 2001; Stewart 2008). Suhrawardī, who was killed under Ayyubid rule in Aleppo, had created the philosophy of illuminationism (ishrāq), drawing on Zoroastrian symbolism; he had made himself enemies among the local religious authorities (Marcotte 2001). The execution of Zayn al-Dīn al-'Āmilī by the Ottomans in Istanbul (Stewart 2008) may have happened against the background of the wider Ottoman-Safavid conflict.

It has recently been argued that a series of uprisings by the Turkish Shiites called "Kızılbaş" ${ }^{21}$ triggered an "Ottoman Sunnitization" (Terzioğlu 2013) in the sixteenth century, "the development of legalistic Sunnism as Ottoman state doctrine" (Dressler 2005, 131) as a double demarcation against the Kızılbaş "heresy" and the Safavid empire. The case of the Kızılbaş/Alevis is a striking example of the paradox and dynamic character of in- and exclusion. In the nineteenth-century Ottoman Empire, the Kızılbaş renamed themselves Alevis by adopting-with the help of Protestant missionaries (Kieser 2001) - the classification of being "heterodox" or "synchretistic" Muslims from Western scholarship as a new self-description. This formula was subsequently not only applied by the new Turkish state and its intellectuals to write Alevis (as TurkishKurdish Muslims) into the secular nation state and to simultaneously marginalize them (as heterodox), but it has also offered the Alevis the opportunity to develop a new standardised and dogmatic form of Alevism in recent decades (Kreyenbroek 2005; Langer and Simon 2008, 285-287; Dressler 2013). Other religious minorities, formerly classified by Muslim heresiographers as "heretics" or "extremist Shī'îs" (ghulāt) and by Western scholars as "heterodoxies," have also started to transform their oralbased traditions and practices in similar ways into more standardised modern canons (Kreyenbroek 2005). A peculiar case in point is Yezidism, which can historically be regarded as an offshoot of a Șūfī movement in the twelfth century, though it soon developed into a religion in its own right, especially in the eyes of modern Yezidis

21 The name "Redhead" refers to their red headgear worn by followers of the Safawid Shah. 
(Kreyenbroek 1995; Langer 2010). The dispersal of Yezidis across several nation states in the twentieth century created the need to define Yezidism for different state administrations in order to gain recognition, thus resulting in a kind of a "transnational orthodoxy" (Langer 2010). In other words, what others had called an Islamic heterodoxy finally ended up creating its own non-Muslim orthodoxy, and thus a case of internal Muslim diversity transformed into external diversity.

The second example of non-diversity is the Muslim attempt to mark a space that is explicitly not multi-religious, the haram districts in the Hijāz, which non-Muslims are forbidden to enter and to reside in. ${ }^{22}$ The ruling is derived from a saying by Muhammad and from accounts of early Muslim scholars that in the time of the second caliph 'Umar b. al-Khațțāb (d. 644), the Hijāz, or the whole Arabian Peninsula, was freed from the presence of non-Muslims through expulsion (Munt 2015, 250). On the one hand, the ruling has been debated by Muslim scholars for several centuries, and the existence of Jewish and Christian communities within the Hijāz and the Arab Peninsula has been reported by various Muslim sources for several centuries (Munt 2015, 251, 259-261). On the other hand, this kind of marking an exclusively Islamic space, in turn, leaves the overwhelming swaths of dār al-islām unmarked, thus implicitly affirming its multireligious nature. Throughout the history of Islam, the common visit of sacred sites by different believers is attested all over Africa, Europe, and Asia (e.g. Hasluck 1929; Fowden 1999; Hayden 2002; Cuffel 2003; Cuffel 2005; Bowman 2012; Couroucli 2012). As Doris Weltecke $(2012,73)$ has argued, such multi-religious sites "were considered neither entirely bizarre nor exactly quotidian". Discussing several examples of "powerful Christian saints" that were also venerated by Muslims, she differentiates between different social and political practices at these sites according to the circumstances. Thus, forms of "spatial," "non-egalitarian," and sometimes "egalitarian" convergence at multi-religious sites can be differentiated according to the object of veneration, the participants involved as well as their motifs, and the dynamic relationship of power and legitimacy. The different spatial arrangements also reflect different uses; historically, sites of multi-religious contact and exchange were used to stage universalism and unity, express power and legitimacy, or mediate in religious disputes and contradictory claims (Beinhauer-Köhler 2015).

The third example revolves around the long-standing relations between Buddhism and Islam (e.g. Elverskog 2010; Yusuf 2010 and idem. 2013; Truschke 2018) and questions the formerly widespread consensus that Buddhism went extinct in India because of "the power of the Islamic sword" (Truschke 2018). A special place in this narrative has been reserved for a Mamluks' raid of Nalanda, the biggest Buddhist monastery

22 For the emergence of the haram districts, see my article "Where Do the Multi-Religious Origins of Islam Lie? A Topological Approach to a Wicked Problem" in this volume. 
in eastern India, because it is said to have signalled the death of Indian Buddhism in 1202. As Elverskog (2010) argues, the Buddhist rulers arranged themselves with their Muslim overlords, and teaching at Nalanda carried on for more than another century; the dharma remained in India until the seventeenth century: "In other words, Buddhists and Muslims lived together on the Asian subcontinent for almost a thousand years" (ibid., 2). The pertinence of the narrative about Muslim barbarism is partly explained by the fact that the British used it to justify the imposition of their own colonial rule in the face of Moghul rule in India and that it feeds into the stereotypes of peaceful Buddhism versus violent Islam. However, spaces such as the Silk Road or Mongol Iran provided opportunities where Muslim scholars and Buddhist monks engaged with each other in theological discussions and new ways of thinking (Elverskog 2010). Vaziri (2015) has recently analysed the Buddhist impact on the famous Persian mystic Jalāl alDīn al-Rūmī (d. 1273). According to Vaziri, al-Rūmī rebelled against the scholastic and hierarchical Islamic establishment with his philosophy of non-dualism, especially in his Dìwān-e kabìr, where he treated central philosophical and anthropological concepts that show clear parallels to advaita Vedanta and Buddhism. Classical Orientalist scholarship already paid some attention to parallels between Buddhism, on the one hand, and Islam and especially Sufism, on the other (Goldziher 1903; Nicholson 1914, 16-27). Vaziri's interpretation, however, calls into question the very notion of two distinct "religious" traditions and presents al-Rūmī as an transcultural and Universalist philosopher. Here, the question arises whether a religious category for al-Rūmī would be adequate at all. Yet locating his ideas in a multi-religious landscape in which different ideas about the meaning of life are negotiated still makes perfect sense.

\section{The Perception of Jews and Șūfīs as Inside Outsiders of Islam}

The term "Islam" is not only characterized by the inclusion of Biblical material (in the Qur'ān), but also by the presence of Jews and Christians (under Muslim rule). Therefore, it is possible to state that the boundaries of Islam include Jews and Christians to a certain degree, especially if one thinks, as does Shahab Ahmed (2016), for example, that the term "Islam" encompasses religious ("Islamic") as well cultural ("Islamicate") meanings. Ahmed (2016, 174f.) believes that an Arabic-speaking Jewish philosopher like Maimonides not only belongs to the context of Islam, but that he is, in effect, an "Islamic Jewish thinker", though not a Muslim one. Although this differentiation is not 
convincing for Ahmed's critics (e.g. Griffel 2017, 14)23, it seems adequate to me to see Jews, Christians, and unconventional believers like Șūfīs as "inside outsiders" of Muslim societies; they not only exchanged ideas among each other, ${ }^{24}$ but their mere existence challenged the spatial practice of clearly distinguishing between inclusion and exclusion. In so far as their belonging to Muslim societies posed a challenge for religious and political authorities, they were subject to different forms of arrangement and treatment throughout history and attracted the attention of observers beyond the borders of Muslim empires. The positions of Jews and Șūfis under Muslim rule form a central point of reference for Muslim as well as non-Muslim perceptions of Islam.

The presence of Jews in early Islamic sources-alongside Christians-has been interpreted as the expression of a special relationship between the Abrahamic religions, yet sometimes also as a danger for the purity of Islam. According to early Arabic sources, Yemeni Jewish converts, such as Ka'b al-Aḥbār (d. 652) and 'Abdallāh b. Salām (d. 663), were among the main informants who contributed to the emergent genre of isrā'illiyyāt, a body of narratives of Biblical background that include legends about former prophets (qișaș al-anbiyā') which did not directly appear in the Qur'ān and Islamic literature (Vajda 1978). This material gained much currency in historiography and tafsïr works because it helped to explain Qur'ānic verses as well as material from the Hadīth literature. While scholars in early modern times were divided about the usefulness of these additional Biblical narratives and the Jewish converts' trustworthiness, the genre of isrā'illiyyāt has been severely criticized in modern times, especially in the twentieth century (Lang 2015). The figure of the "arch-heretic" 'Abdallāh b. Saba', whose conversion is mentioned by pro- and anti-Shī'i authors since the end of the eighth century (Anthony 2011, 1f.), plays an important role in religious polemics, as he is said to have propagated an array of insidious doctrines after hisprobably feigned-conversion. While liberal authors in the twentieth century, such as Ṭāhā Husayn (d. 1973), contested the historicity of the reports about Ibn Saba', this figure was used to discredit the Shī'a because of Ibn Saba"s alleged relations to early "Shī'ī" protagonists and also served as an early example of a Jewish conspiracy against Islam (Ende 1977, 199-210). Another example for such a conspiracy theory concerns the Dönme from Salonika - a movement going back to Shabbatai Tzevi (d. 1676), who proclaimed himself the messiah but later (under pressure?) converted to Islam with his adherents; according to the proponents of the conspiracy theory, the Dönme controlled the Young Turk movement of 1908 and still controls the Turkish Republic and even Turkish Islamists (Baer 2004; 2007; 2010).

23 Griffel $(2017,14)$ remarks that "one should not expect any cultural product not to be Islamic given that it all belongs to the context."

24 For the reciprocal exchange between Jews and Șūfīs especially in Mamluk Egypt see Fenton (2017). 
In spite of such negative judgements of Jewish influences on Islam, European Jewish scholars in the nineteenth and the twentieth centuries played a key role in the development of a nonpolemical evaluation of Islam in European academia, thus acknowledging and sometimes romanticizing the merits and achievements of "Muslim civilization" (Kramer 1999). This "Jewish discovery of Islam" (ibid.) can be traced back to Abraham Geiger's (d. 1874) Was hat Mohammed aus dem Judenthume aufgenommen? (1833), which was followed, among others, by Ignaz Goldziher's (d. 1921) studies. In these works, Islam and Judaism appeared as kindred faiths-an approach that strongly influenced the emergence of modern Islamic studies in Europe and the USA and undermined the idea that East and West were polar opposites. As "mediators between Europe and Islam" (Kramer 1999, 5), Mediterranean Jews, in particular, posed a challenge to the dichotomies on which modern Europe was constructed in the nineteenth and early twentieth centuries: Christendom versus Islam, Europe versus Asia, Aryan versus Semite. Jewish scholars' views rested on the argument that Jews had helped to bring the civilization of medieval Islam to its apex and could do the same for the civilization of modern Europe; hence the active association of European Jews with Islam in the nineteenth century, which was even reflected in the construction of urban synagogue architecture in "Moorish" style.

In recent decades, a renewed interest in the Jewish history on the Arabian Peninsula has tried to ascertain what kind of Jews lived in and around Medina in pre-Islamic and early Islamic times (Lecker 1985; 1995a; 1995b; 2012; 2016; 2017). For the pre-Islamic presence of Jews, there are, however, only indirect clues through scattered inscriptions, which point more or less conclusively at Jewish names and expressions (Hoyland 2011)-apart from accounts about the Himyarites of Yemen who adopted Judaism in the sixth century.

The Muslim and non-Muslim interest in the mystics of Islam follows a somewhat different trajectory. Șūfīs are known for their eccentric practices, appearances, and views. Al-Ḥusayn b. Manșūr Ḥallāj, who was crucified in Baghdad in 922, had not only built "a model of the Ka'ba at his home for private worship" (Mojaddedi 2013) and advocated the building of further replicas for those unable to travel to Mecca; he also uttered "I am the Truth" (anā I-haqq) - "the most notorious of all theopathic utterances (šațahāt) recorded in the history of Sufism" (ibid.). Other mystics prayed by hanging upside down (čella-ye ma'kūsa/namāz ma'kūs); by so doing, Abū Sa'īd Abī l-Khayr (d. 1049) claimed that his body had become the qibla (direction of prayer) (Vaziri 2015, 184). The Șūfi insight that "the striving for God through exercises of self-denial leads to self-centered religious practice" (Böwering 1983) also made the Șūfīs level harsh criticism at outward religiosity, expressed in the verses attributed to Abī I-Khayr: "Not until every mosque beneath the Sun/Lies ruined will our holy work be done;/And never 
will true Muslim appear/Till faith and infidelity are one" (Vaziri 2015, 185; Nicholson 1914, 90).

Irrespective of the condemnation of some Șūfĩ practices and views by scholars like Ibn Taymiyya (d. 1328), Imam Birgivī (d. 1579), Muhammad b. 'Abd al-Wahhāb (d. 1792), or by reformers of the nineteenth and twentieth centuries, Șūfīs were mostly regarded as part of the Islamic mainstream and often enjoyed popular support as well as the rulers' patronage, especially in the Mughal, Safawid, Ottoman, and Sokoto empires; they were a cause for perplexity rather for scholars of religion than for Muslims themselves (see O'Fahey and Radtke 1993; Radtke 1994; van Ess 1999), especially since the supposedly spiritual leaders of Șūfĩ brotherhoods often led the anti-colonial resistance against European powers in the nineteenth century.

Some scholars of religion even tried to racially divide Islam into an Aryan-Șūfī and an Semitic-Sunnī branch, arguing that Sufism showed signs of Aryan creativity since it was too intellectually demanding to have been blossomed from the heart of true Islam (Masuzawa 2005, 197-204). In a similar vein, Ibn 'Arabī (d. 1240), defamed by some Sunnī scholars because of the possibly pantheistic concept of wahdat al-wujūd ("unity of existence") ascribed to him, rose to recognition among the critics of conservative and salafĩ scholarship. The European converts to Islam Ivan Aguéli (d. 1917), René Guénon (d. 1951), and Frithjof Schuon (d. 1998) turned Ibn 'Arabī into their principal witness for perennialist universalism, within which also lurked the spectre of Aryanism (Lipton 2018; 2017). Although Ibn 'Arabī welcomed diverse interpretations of Qur'ānic verses, it is possible to argue that he subscribed neither to pluralism nor to relativism in religion-in spite of some famous verses that give this impression. ${ }^{25}$

In his dissertation of four volumes on al-Hallāj (1922), the French Orientalist Louis Massignon (d. 1962) followed a different approach to Sufism by drawing parallels between the passion of the "martyr mystique de I'Islam" (Massignon 1975) and Jesus Christ. Massignon, who had converted from agnosticism to Catholicism in Iraq and Lebanon around 1907, strove to understand Islam from the inside but criticized the Islamic negation of incarnation; he later joined the Melkite Greek Catholic Church, whose liturgical language is Arabic, because he thought that this would bring him as close to Islam as one could possibly get as a Catholic.

At the beginning of the twenty-first century, after several attacks on Șūîs by radical groups, a politicized division between Sufism and orthodox Islam has re-

25 See, for example, the often quoted Poem XI from the Tarjūmān al-Ashwāq: “My heart has become capable of every form: it is a pasture for gazelles and a convent for Christian monks, / And a temple for idols and the pilgrim's Ka'ba, and the tables of the Torah and the book of the Koran. / I follow the religion of Love: whatever way Love's camels take, that is my religion and my faith" (Ibn 'Arabī 1911, poem XI, lines 13-15). 
surfaced in popular media to give credit to the conceptualization that "Islam is understood as inherently intolerant and incompatible with Western secularism, while Sufism (commonly referred to as Islamic mysticism) is claimed to be profoundly tolerant and secular because similar to Christianity" (Lipton 2011, 427). Thus, as Lipton (2011, 427f.) notices, "Sufism functions in current US political discourse as a template for an 'alternative' Muslim subjectivity (...) more readily in tune with the ethos of American individualism, liberalism, and neoliberal privatization."

\section{The Global Circulation of Ideas about Islam}

The trope of Islam's anti-Trinitarianism circulated in different ways across time and regularly reappeared at turning points in history. Thus, it left its imprint on European debates about the nature of Turks and Native Americans, the confessional quarrels following the Reformation, and debates about religious tolerance and slavery during the Enlightenment. Anti-Trinitarianism is among the "stereotypes that have dominated Western Christian discourse about Muslims since the reception of John of Damascus' depiction of Islam as a heresy" (Ralston 2017, 756). While it basically marked Islam as a Christian heresy, it later also turned into a positive ascription. The idea that Muhammad "had revived an early, truer form of Christianity, in which the Trinity and Jesus's divinity were later corruptions" (Spellberg 2013, 68) was already circulating underground in mid-seventeenth-century England; it was articulated in an unpublished treatise by John Locke's fellow student of Arabic, Henry Stubbe (d. 1676), who fostered "Unitarian"26 ideas about God (Garcia 2012, 1-59). A group of Muslims in London finally succeeded in publishing Stubbe's treatise in 1911 (ibid., 225-231). Thus, the scholar of Qur'ānic studies Günter Lüling's (1993) approach, arguing that Islam represents an early and pure form of Christianity, is not without precedent. ${ }^{27}$

With the fall of Constantinople (1453 CE), the anti-Trinitarian nature of Islam was, for example, perceived differently, respectively, by Nicolaus Cusanus (d. 1464) and Enea Silivio Piccolomini (d. 1464), the later Pope Pius II. While Piccolomini held that the antiTrinitarian stance of Islam was a heresy that should be fought militarily, Cusanus tried to convince him that Islam and Christianity were closely related and dialogue should be the first option (Poppe 2014). In De pace fidei ("On the Peace of Faith," 1453), written under the impression of the fall of Constantinople, Cusanus argued against the crusade idea; in Cribratio Alkorani ("Sifting the Koran", 1460/61), he maintained that all Christian

26 This first use of the term in English print dates from 1672 (Spellberg 2013, 322).

27 For more on Lüling's approach, see my article "Where Do the Multi-Religious Origins of Islam Lie? A Topological Approach to a Wicked Problem" in this volume. 
doctrines were, at least in nuce, to be found in the Qur'ān, even the idea of the Trinity, which Islam openly renounced (Rudolph 1994, 101 and 105). To explain this closeness, Cusanus, drawing on the Bahīrā legend ${ }^{28}$, stated that Muhammad had been educated by a Nestorian monk named Sergius as a Nestorian Christian, but was later diverted from the true faith by three sly Jews (ibid., 103). In several places, Cusanus's attempt to co-opt Islam rested on a misreading or misinterpretation of the Latin translation of the Qur'ān (ibid., 105-107).

The same trope also played a role in the famous dispute between Bartolomé de las Casas (d. 1566) and Juan Ginés Sepúlveda (d. 1573) over the rights of indigenous peoples in newly discovered America, in which the imago Turci lay at the core of the dissent. "Where Las Cases tried to prove that the Indians were not 'Turks' and should be treated differently, that is peacefully, Sepúlveda extended the European attitude towards the Turks to the treatment of the Indians" (Mastnak 1994, 127). The underlying rationale in this dispute was an internal dialogue of Europeans with themselves and with Thomism, first, to determine what Christians were allowed to do to infidels and pagans and still feel just and virtuous and, second, to refute the Lutheran theory of dominium and sovereignty, which was based on God's (volatile) grace, not on a Papal bull (ibid., 130; Pagden 1987). In this respect, the disputants and the conquistadores shared the view that the conquista in Latin America was the continuation of the reconquista in Spain (Mastnak 1994, 139), and that crusading had not come to an end but was still justified. Where Sepúlveda used his arguments for war against the Turks to also justify war against the Indians, Las Cases constructed a difference between Muslims and Native Americans; in other words, his love for Indians fed on his hatred for Turks, Moors, and Saracens. Las Casas could only "argue for peaceful treatment of the Indians because he accepted the justice of war against Muslims" (ibid., 144), charging Sepúlveda "with the desire to spread the faith with 'Mohammedan method', that is, "with death and terror" (ibid.). References to the Turks were "an organizing principle" (ibid., 140) in both the disputants' reasoning. Mastnak (ibid., 131) therefore thinks that "once we see how much the image of the 'Turk' determined the sixteenthcentury debate over the Indians, it becomes clearer how much our own story of the discovery of the New World, overlooking as it does that central, fictious, figure of the Turk, continues to be wrapped in fictions."

Since the early times of the Reformation, Catholics as well as Protestants used the figure of the Turk to discredit one another's dogma and construct a close relationship of their opponents to Islam. Most Protestants in Europe and America described and

28 According to Muslim biographers of Muḥammad, the monk foretold Muhammad's prophethood when he met him as a young man; in the Christian tradition, the heretical monk's ideas are said to have inspired the Qur'ān. 
depicted the Antichrist "as a beast with two heads-one a mitered pope and the other a turbaned Ottoman Sultan" (Spellberg 2013, 15; Kidd 2003; Ralston 2017). Yet while religiously legitimatized violence raged in the sixteenth and seventeenth centuries, a minority of Catholics and Protestants spoke out against violence and defended Muslims and Jews from coerced conversion, state persecution, and violence. Although their "ideas were never considered acceptable while they lived" (Spellberg 2013, 40), these ideas evolved over the centuries and were eventually espoused by the Founding Fathers of the USA, as Spellberg (2013) has shown.

Thus, a twisted line of thought and argumentation, drawing on images of Islam ${ }^{29}$, connects Michael Servetus (d. 1553) and Sebastian Castellio (d. 1563) to John Locke (d. 1704) and Thomas Jefferson (d. 1826). The immolation of Spanish theologian and humanist Michael Servetus at the gates of Geneva in 1553 found widespread approval in Europe because both Protestants and Catholics condemned his ideas. Inspired by Erasmus's (d. 1536) annotations to the New Testament-especially by Erasmus's view that the "Johannine Comma" was a later interpolation to the Latin Vulgate, not contained in early Greek texts ${ }^{30}$-, Servetus concluded that the doctrine of the Trinity had no basis in the Bible (Bietenholz 2009, 33-37; McDonald 2017, 70f.). Fleeing from the inquisition in France to Geneva, Servetus asked John Calvin (d. 1564) why Jews had been expelled from Spain in 1492 and Muslims persecuted for refusing "a concept not found in Christian scripture, and whose abstruse nature remained a barrier to the ultimate Christian aim of the conversion of both Jews and Muslims" (Spellberg 2013 , 48). A year after the public immolation of Servetus for heresy, Castellio, under a pseudonym, composed a treatise in which he deemed the persecution of heretics unchristian, arguing that "to kill a man is not to defend a doctrine. It is simply to kill

29 As mentioned above, the terminology in early modern Europe with regard to Muslims was not stable and did not refer to a faith called "Islam" in French and English before the late seventeenth and early nineteenth century, respectively. Here and in the following examples, "Islam" is therefore not the term used in most primary sources but the analytical tool with which I access the unifying talk about the Muslim (Turk, Saracen, etc.). Other in order to lay bare the multi-perspectivity connected with this talk.

30 The "Johannine Comma" in the First Epistle of John (5: 7-8), which was seen as a confirmation of the doctrine of the Trinity, seems to have originated as a gloss of the Vulgate in the fourth century (Houghton 2016, 178). Erasmus excluded it in the Greek text and in his Latin translation of the first printed New Testament of 1516 and 1519, and assumed that it was introduced in the course of debates with the anti-Trinitarian Arians. Martin Luther, who based his German Bible translation on Erasmus's work, also excluded the Johannine Comma. In order to avoid excommunication, Erasmus re-introduced the Comma in the third edition of 1522; from this edition, it became part of the King James Bible (1611). The Comma was also introduced into the Luther Bible from the seventeenth to nineteenth centuries. The Nova Vulgata (1979) no longer contains the phrase. I thank Markus Müller for drawing my attention to Erasmus's work. 
a man" (quoted ibid., 49). Convinced of Christianity's superiority, he did not believe that Muslims, as anti-Trinitarians, were equal as believers, but that religious strife "did nothing to further the salvation of non-Christians" (ibid.).

Thomas Helwys (d. 1616), who later founded the first Baptist church in England, published similar ideas when in exile in Amsterdam; he died in Newgate Prison in London because of his conviction that state and church should be separated (ibid., 53-55). The inclusion of Muslims in the defense of religious freedom was also argued for by Roger Williams (d. 1683), who opposed the Puritan theocracy in Massachusetts that persecuted, jailed, and killed Christian dissenters-Baptists, Quakers, Anglicans, and Catholics-as well as non-Christians. After business contacts with the Ottoman Empire and North African states intensified under the rule of Elizabeth I in 1580, and after Oxford University established a chair in Arabic in 1636, knowledge about Islam grew and became central to tolerationist debates in late seventeenth-century England because of the alleged similarities between Islam and the anti-Trinitarianism of Deists and Socinians. When Jews were allowed to return to England in 1656 for the first time since the Edict of Expulsion (1290), Muslim diplomats and traders also seem to have practiced their faith privately without government interference (ibid., 71). Whereas Locke had formerly rejected toleration for Christian dissenters, while including Jews and Muslims, he reversed his views and included them in the Latin version of his A Letter Concerning Toleration (1689), the English translation of which, however, omitted the anti-Trinitarian Christian Socinians (ibid., 75).

In America, Thomas Jefferson-an anticlerical Christian strongly influenced by Deist authors-took Locke's argument for religious freedom one step further when he pleaded against an established state church, thus following the petition of Protestant dissenters. Jefferson was not only an admirer of Locke, but also bought George Sale's first English translation of the Qur'ān from 1734 and immersed himself in the studies of the history of Islam, positively noting the Ottoman toleration of Christians (ibid., 68). While Locke's argument supports the toleration of Jews and Muslims under an Anglican government, Locke did not expect their salvation, save they converted. Jefferson, however, believed that "it was not for the state but the individual to be concerned about his own salvation" (ibid., 108). While his opponents pressed him on whether he really wanted to have a Muslim as future president (Spellberg 2006), Jefferson followed his own line of argumentation. On the one hand, in his speeches in the Virginia House of Delegates against state religion he compared the Anglican Church to Islam for his purpose to end the Anglican establishment in Virginia, thus using the long-standing Protestant polemical approach to denigrate both Catholicism and Islam. On the other hand, Jefferson left behind a Christian frame of reasoning regarding tolerance, thus using the case of Muslims and Jews in order to extend toleration to all faiths, including 
atheism (Spellberg 2013, 107, 111-123). Until the end of his life, Jefferson was proud of the Virginia Statue of Religious Freedom, drafted by him in 1777 and ratified in 1786, and believed that it had put into practice his universal visions of the equality of men. The "paradox of liberty" is, however, that Jefferson extended religious liberty to Catholics, Jews, and even Muslims, while he excluded black African and mixed-race slaves from his considerations. Muslim slaves probably outnumbered the 2,000 Jews and 25,000 Catholics at the inception of the United States, although it is impossible to ascertain the exact percentage of Muslims among the slaves who arrived in Virgina since 1619 and numbered more than 120,000 in the mid-eighteenth century (ibid., 121). ${ }^{31}$ While two or possibly four Muslim names among the 300 slaves owned by George Washington have been identified, the same has not yet been possible with regard to Jefferson's more than 600 slaves (ibid., 122). It is rather telling that in recent years, a consensus about Jefferson's personal life emerged among historians, saying that he fathered several children with his slave Sarah (Sally) Hemings (d. 1835) and had an African-American family, a fact rumoured about but kept secret for almost 200 years (Gordon-Reed 2008).

In this context, it is worth mentioning that the "first collective Christian statement against slavery" (Meggitt 2013, 76) in the British colonies, the 1688 Germantown Declaration by Quakers in Pennsylvania, is based on experiences and arguments that connect the Transatlantic slave trade with its Mediterranean counterpart. As the Quakers had to endure persecution and imprisonment and sometimes even fell victim to executions in England and the colonies, especially in the period between the Quaker Act (1662) and the Act of Toleration (1689), Quaker captives in Morocco and Algiers, paradoxically, "were freer to practise their religion as slaves in Barbary states than they were in England" (ibid., 53), although they suffered mistreatment here as there. This experience gave George Fox (d. 1691), the founder of the "Religious Society of Friends," in the late 1640s, "a concrete example with which to shame Christian authorities who prevented Quakers from meeting" (ibid., 55). The Quakers' zeal to spread their message throughout the world resulted in a number of encounters with Muslims and, in spite of the danger of enslavement, a benevolent attitude towards them. In 1658, the itinerant preacher Mary Fisher (d. 1698), one of the so-called "Valiant Sixty," was able to meet Sultan Mehmet IV in Adrianople, who listened respectfully to her and offered a military escort for her safe return to Istanbul, which she declined. The episode stands in contrast to Mary Fisher's experiences in Cambridge, England in 1653, where she was

31 The speculations range between ten to thirty percent (Considine 2018, 1). The early history of free and enslaved Muslims in the Americas is beyond the scope of this contribution. For a short overview of the Muslim presence since the sixteenth century see Curtis 2009; for the discursive use of Islam before US Independence see Kidd 2003. 
stripped to the waist and flogged, and in Boston, Massachusetts in 1656, where she was detained on arrival, forced to undress in public, jailed, and forcefully expelled, while her books and pamphlets were burnt (ibid., 60-62). Although the Quakers' experience with Islam, ranging between enslavement and tolerance, was two-sided, they dissociated the immorality of Muslims' acts from the morality of their religion, which was rather uncommon in the seventeenth century (ibid., 67). The four Quakers, who composed and signed the Germantown Declaration against African-American slavery, began their text with "a plea for empathy and remind (...) the reader of their fear of being captured at sea by 'Turks' and sold into slavery" (ibid., 76). By so doing, they did not draw on an anti-Turkish trope but opposed slavery from a universalist perspective by placing their co-religionists' experience with enslavement on a par with the slavery experienced by Africans in the British colonies. Thus, the declaration is a document of cultural intersections, showing that there is a "clear link between the origins of the movement to abolish slave trade in Africans and the Quaker's experience of Barbary slavery" (Meggitt 2013, 75f.). ${ }^{32}$

\section{European Knowledge Production about Arabic Philosophy and the Qur'ān}

As these examples show, ideas about Islam held and still hold a central place in European-American intellectual history. Even if these ideas about Islam did not directly deal with Muslims, they formed useful bargaining tools that helped to negotiate the treatment of Turks, Native Americans, Protestant dissenters, Catholics, Jews, and slaves. While knowledge production about Islam played an important role in this regard, the different uses of translations of Arabic texts and the Qur'ān by European writers, scholars, and theologians are too numerous to fit into one category, since they ranged from outright hostility or polemics to a humanist engagement with the text itself (Elmarsafy 2009).

The first translations from Arabic to Latin date back to the late tenth century and concern the use of the Astrolabe (Hasse 2013, 378). From the late eleventh to the thirteenth century, the translation of a vast amount of different texts, among them mathematical, astronomical, philosophical, and medical texts, took place in several waves in Italy and Spain and had a strong impact all over Christian Europe. Although there seems to have been a halt of the translation movement between 1300 and 1480,

32 The declaration was not adopted by the Quaker community and even forgotten, so that it was rediscovered twice (in 1844 and 2006) (Gerbner 2007, 150). Slavery continued in Quaker society and abolitionism remained an outsider position among Quakers for another hundred years. 
the reception of Averroism peaked around 1500, and several printed works appeared until the mid-sixteenth century, when the first chairs for Arabic were founded in Paris, Leiden, Cambridge, and Oxford (ibid., 385).

Interestingly enough, the impact of the translated works by philosophers and theologians such as Ibn Rushd, known as Averroes (d. 1198), and al-Kindī (d. 873) in Latin Christian Europe was much more profound than the reception of the original treatises in the centers of Arab and Muslim learning, where the manuscripts hardly found any readers and were re-discovered only in later centuries because of transmission in Latin Europe (ibid., 382f.; Kügelgen 1994). In Latin Europe, adherents and opponents of Averroism in scholastic as well as humanist circles eagerly received and discussed the pros and cons of theories put forward by al-Fārābī (d. 950), Ibn Sīnā, known as Avicenna (d. 1037), and Ibn Rushd-such as Ibn Rushd's theories about the "unity of the intellect"33 or the eternity of the world (Fakhry 2001; Haase 2013, 392-396). The translated Arabic texts played a central role in scholarly discussions for several centuries and forged the self-awareness of Christian and humanist scholars (ibid., 396); they were also appreciated by Jewish scholars, who followed the recommendations by Ibn Rushd's contemporary Maimonides to read them.

It is intriguing that these texts, which were widely circulated through Hebrew and Latin translations, created a positive image of the "rationality" of Muslim thought, although the multi-perspective, foundational discussion about the relation between reason and religion among Muslim authors from the eleventh to the fourteenth centuries (see Kügelgen 2010) was only fragmentarily known, some of the Arabic texts only partially translated, some of the circulating arguments misattributed, and their historical background misidentified or unknown. It is further intriguing that because of Ibn Rushd, Islamic philosophy stood as an antidote to religious strife, while Ibn Rushd himself might have been "an unexpected target of the anti-Jewish climate created by the Almohad authorities" (Serrano Ruano 2010, 230) and condemned along with several other philosophers. Ibn Rushd's fall from grace after 1194-obviously after an intrigue culminating in a caliphal decree accusing philosophers of being "worse than Christians and Jews" (ibid., 223)—was the result of a still unresolved, complex process that involved humiliating treatment of Ibn Rushd, accusations of unorthodox beliefs ("anthropomorphism"), and a rumor of his alleged Jewish ancestry. As his religious and intellectual integrity and his political loyalty were questioned, he was banished to Lucena, a small town traditionally populated mainly by Jews, for one-and-a-half years

33 Drawing on the universality of knowledge and the immateriality of the intellect, Averroes developed the theory of the unity of the human intellect, criticized by Thomas Aquinas (d. 1274) in De Unitate Intellectus, Contra Averroistas and condemned by the Catholic Church in Paris in 1270/1277 and again in Padua in 1489. 
and then summoned by the caliph to Marrakesh, where he died, never returning to Cordoba.

A telling example of the lack of this background knowledge is the image of Islam in the manuscript Colloquium Heptaplomeres ("The Colloquium of the Seven"), which has been called "one of the strangest and most fascinating texts written in early modern Europe" (Malcolm 2006, 95). The work, commonly attributed to French political philosopher Jean Bodin (d. 1596) (Malcolm 2006), was widely circulated, clandestinely, since the 1620 s before being printed in the mid-nineteenth century. It tries to solve the problem of how to deal with religious strife and a growing religious diversification in the course of the Reformation, and reproduces the debates of seven wise men-a Roman Catholic, a Lutheran, a Calvinist, a Jew, a Muslim, a natural philosopher, and a skeptic. In his search for models that could help Europeans solve the difficulties of multi-religious coexistence on the social, religious, and state level, the author heavily draws on examples from Antiquity but also from Judaism and Islam (Griffel 1999, 120). The image of Islam is that of a consistently tolerant religion $a b$ initio that allows the practice of foreign rites and forbids any quarrel about true religion. In the fourth book, the Muslim sage ("Octavius") claims that under the Turkish and Persian kings, who tolerate every form of religion, a harmony between citizens and foreigners prevails and reconciles the adherents of different religions with the state (ibid., 121). Thus, Islam comes close both to natural religion and the Bodin's ideal.

Griffel (1999, 131-142) has shown that Bodin knew only Ibn Rushd's main line of argumentation, but not al-Ghazālī's (d. 1111) arguments, which Ibn Rushd had criticized. Ibn Rushd's work Tahāfut al-tahāfut (ca. 1179 CE) was translated twice via Hebrew into Latin in 1328 and 1526, and printed as Destructio destructionum in 1497/1508 and six more times in the sixteenth century. Bodin obviously knew Ibn Rushd's argumentation, but mistook it for the position of Islam as such and had no idea about al-Ghazālī's, Avicenna's, or Ibn Taymiyya's positions, all of which had much more impact on the formation of Sunnī Islam (Griffel 1999; Kügelgen 2010). Bodin also seems to have taken the foundations of his own principle of toleration from Ibn Rushd, since his text reflects Ibn Rushd in three arguments, as Griffel $(1999,144)$ argues: All religions teach the same universal law and are only different ritual manifestations; these manifestations are intended to guide illiterate people to the moral law; although the educated can grasp the universal moral law behind these manifestations, they should avoid interpreting it for ordinary people and adopt the "most noble" among the religions of their time. Maybe Ibn Rushd's view about the difference between a theological and philosophical understanding of religion seemed attractive to Bodin because it may have helped him to differentiate the religious fanaticism of the "masses" during the Reformation from a pragmatic approach to religion advocated by literati like himself. 
That there was a discrepancy between the known historical facts and an idealized Islam in Latin Europe is even visible in the field of historiography. The Dutch Orientalist Thomas Erpenius (d. 1624) managed to translate the second part of the chronicle by the Egyptian Christian Jirjis b. al-'Amīd (known as al-Makīn, d. 1273) as Elmacin's Historia Saracenica (1625). With this work, Erpenius thought to provide a historical chronology of events since Muhammad unknown hitherto to European scholars. As he was unaware that the original text mainly drew on early Muslim sources, he actually made a "Muslim version of Muslim history available in Europe for the first time" (Irwin 2007, 103).

While the reception of Arab knowledge was controversial yet considered unavoidable in the emerging European scientific, philosophical, and medical landscape, the reception of the Qur'ān met with more reservations. Polemics against the person of Muhammad go way back to Johan of Damascus (d. 749), who already depicted Muhammad as a false prophet and the Antichrist and Muhammedan faith as a Christian heresy. The first "anti-hagiography" of Muhammad written north of the Alps in Latin can be attributed to a certain Embrico of Mainz, around 1100 (Tolan 1996). One of the most influential polemics ever written was Contra legem sarracenorum (ca. 1300), which was composed by the Italian Dominican monk Ricoldo da Monte di Croce (d. 1320) during or after his visit of Baghdad, first published as Confutatio Alcorani (1500) in Seville and translated into German by Martin Luther (d. 1546) as Verlegung des Alcoran (1542) (see Ehmann 1999; 2008). The polemics stressed the irrational and illogical character of Muhammad's teachings. In early book printing, illustrations of Muhammad visualized this message by depicting him as the false prophet, anti-hero, heretic, warrior, forger, Turk, and anti-Christ (Saviello 2015). These visualizations were meant to show the true picture of Muhammad; they took issue not only with his adherents' veneration for him, but also with a perceived Muslim lack of religious images. The prophetic iconography that circulated in the Turco-Persian and Mughal sphere since the mid-thirteenth century (Gruber and Shalem 2014) was mostly unknown to Europeans at that time. ${ }^{34}$

The first translation of the Qur'ān into Latin by Robert of Ketton in 1143 was appropriately titled "Lex Mahmut pseudoprophete" (Würsch 2013, 41). Petrus Venerabilis (d. 1156), Abbot of Cluny, who had ordered it in the aftermath of the first crusade (1096-1099), held the view that "the Islamic heresy" could only be defeated with the word, not with the sword. In spite of many shortcomings, this translation was considered authoritative by Latin Christians for 500 years and formed the foundation of the first print edition that the Zurich reformed theologian Theodor Bibliander (d.

34 The illustrations of the chronicle Jāmi` al-tawārīkh (1306-1311) (Blair 1995; Hillenbrand 2014), for example, contradict the cliché (widespread among both Muslims and non-Muslims) of a lack of religious images that has, purposefully or not, had the effect of eclipsing the artistic patrimony and visual imaginary within Islam (Gruber and Shalem 2014, 4). 
1564) initiated in Basel in 1543 (Bobzin 1995). That Bibliander himself added his own errors and misunderstandings to the text helps to identify, in the present, the chain of translations that have been based on his print (den Boer and Tommasino 2014, 470). The 1547 Italian translation Alcorano di Macometto by Giovanni Battista Castrodardo, printed in the smaller and cheaper quarto format, enjoyed much popularity among the literati all over Europe and the Mediterranean until 1643, when the first French translation appeared. The Italian version of Bibliander's work also fathered Dutch, Hebrew, and Spanish translations and formed the basis of the first German translation of the Qur'ān (1616, Nuremberg) that was accomplished by the Lutheran preacher Salomon Schweigger, who had learned Italian in Constantinople (ibid., 477).

That the Italian Alcorano was prohibited by the Tridentine Index (1546) shows that its sitz im leben was with the anti-Imperial and anti-Medici circles (ibid., 473-475), since the introduction by Castrodardo contained several anti-Imperial and pro-Ottoman notes. Its printer, Andrea Arrivabene, dedicated the work to the French ambassador to the Ottoman Empire, Gabriel de Luetz. ${ }^{35}$ The readers of Alcorano, both in Venice and Constantinople, consisted of political refugees, anti-Trinitarians, evangelical preachers, as well as Iberian Jewish refugees and conversos (Tommasino 2018, 9296). Among Sephardim Jews in Amsterdam, who had regular contact with the Maghreb and the Ottoman Empire, an increasing interest in the Qur'ān found its expression in the Spanish and Hebrew translation of the Italian Alcorano in the seventeenth century. Like anti-Catholic Qur'ān readers, rabbis and other Jewish authors found an ally in Islam that supported their argument against idolatry (den Boer and Tommasino 2014, 482). The Amsterdam Sephardi Jew Abraham Gómez Silveira (d. 1740), for example, depicted Islam as a rational religion-“only obscured, as are other religions, by human weakness" (ibid., 483). In witty dialogues between a reformed minister, a Catholic theologian, a Jew, and a Turk, the latter not only defends "monotheism, the human nature of Jesus, and the enduring validity of the Torah," but also speaks out "against enforced religion and he advocates natural law" (ibid.).

This was also the context in which Renaissance authors started to paint a new image of Muhammad as a "lawgiver" and "armed prophet" since the late fifteenth century; by focussing on his military and political achievements, they no longer portrayed Muhammad as a "pseudo-prophet," but as a gifted politican and successful builder of an empire, comparable to great Greek and Roman men (Tommasino 2018, 81-91). This background not only explains Niccolò Machiavelli's (d. 1527) several references to Muslim examples, but helps to restore "the centrality of his encounter

35 During the Schmalkaldic War (1546-1547), de Luetz embodied the hopes of anti-imperial groups who wanted to spread the Reformation on the Italian peninsula; during his stay in Constantinople (1547-1553), de Luetz negotiated an alliance with the Ottomans against the Imperial forces. 
with Islam and the East" (Biasiori and Marcocci 2018, 3) in his own works. In particular, Machiavelli's II Principe seems to be indebted to his knowledge of one of the Arab mirrors of princes, the Pseudo-Aristotelian Kitāb sirr al-asrār of eighth/ninth-century CE origin, which was not only "extremly popular in Europe" (Biasiori 2018, 18) but has been termed "the most popular book of the Middle Ages" (ibid.). Translated into Latin and entitled Secretum secretorum around 1125, "over 500 manuscript copies in European vernacular languages and 34 printed edition between 1472 and 1540 in Latin, Italian, German, English and French" (ibid.) are documented, and in Machiavelli's Florence 23 manuscripts have survived until today (ibid., 19). In this respect, "reorienting Machiavelli" (Biasiori and Marcocci 2018, 3) helps to underline the extent to which II Principe and Machiavelli's other works represent "pieces of a wider Eurasian mosaic ..., characterised by incessant political communication across linguistic, cultural and religious borders" (ibid.). Yet Machiavelli's contribution to modern political thought is still "typically reduced to a process entirely limited to the West" (ibid.), if not presented as an approach expressing "the supposed superiority of western values" (ibid.).

In spite of such early modern readings of the Qur'ān in Latin Europe, negative views of Islam prevailed; during the period usually called Enlightenment, a majority of European Qur'ān readers no longer based their prejudice on accusations of heresy but on the apparently boring style and awful language of the book (Wild 1994). However, there were also examples of a positive reception in the eighteenth and nineteenth centuries, such as the German poets Gotthold Ephraim Lessing (d. 1781) and Johann Wolfgang von Goethe (d. 1832), both of whom immersed themselves in studies of the Qur'ān and Muslim history. The judge's admonishment in Lessing's Nathan der Weise (1779) - that the three ring owners should not quarrel about who owned the right ring but compete with each other in performing good deeds-bears close resemblance to Qur'ānic verse 5:4836 (Fick 2017, 40f.; Kuschel 2011). In an announcement of his Westöstlicher Divan (1819, extended 1827), Goethe, in spite of his pantheistic inclinations, did not contradict the suspicion that he was a Mussulman himself (Mommsen 2001, 11). American novelist Washington Irving (d. 1859), whose work turned the Alhambra of Granada into a famous place of Western romantic yearnings, also composed a biography of Muhammad (1850, translated into in German the same year) in which he defended the prophet against the accusation of being an imposter. This work was among the sources from which Friedrich Nietzsche (d. 1900) developed his positive assessment of Islam (Figl 2008, 138f.). Nietzsche, in section 60 of his Antichrist, lamented that Christianity "robbed us of the harvest of the ancient world, and it later went on to rob us of the harvest of the culture of Islam" (quoted by Almond 2010, 157). Nietzsche 
considered "the wonderful Moorish cultural world of Spain, more closely related to us (...) than Greece and Rome" (ibid.), yet it had been "trampled down" by Christianity (ibid.). While the Orientalists of his time criticized Islam as fanatical, misogynic, unjust, and incapable of democracy, Nietzsche used it as "a positive example of a Semitic faith to show by contrast how weak and malign Christianity is" (ibid., 161). He lauded Islam as "more life-embracing and 'manly' than its Judeo-Christian sister-faiths" (ibid.). Although "Islam emerges in Nietzsche's work not as an affirmation of life in itself," it is "the closest thing to a jasagende affirmation the Semitic religions have to offer" (ibid.).

Studying ideas about Islam in the thought of eight German thinkers, from Leibniz to Nietzsche, Almond (2010) describes a polyphonic, complex struggle among them to come to terms with the "Mohammedan" Other and ends on the note-well-suited as a summary of the foregoing considerations-that a clearer understanding "will only take place once we stop thinking of authors as personalities who possess world-views, and start to see them as spaces in which discourses happens" (ibid., 163).

\section{Conclusion}

This article has tried to establish the distinction between the analytical category of Muslim space and the emergence of a trans-religious space, characterized by the circulation of ideas about Islam. In a first step, I aimed to problematize the notion of a Muslim world as a geographical, cultural, or trans-local conception in academic discourses. As a central problem in such conceptualizations, I have identified the different ways in which Islam is inscribed into space and history. My critique further tried to highlight that similar spatial mechanisms are at work when different actors and observers mark spaces-such as outer space, Europe, or the Middle East-as Islamic or un-Islamic or both at the same time. These include political and ritual practices, imagination, investment, planning, and popular use as well as scholarly debates. The scientific and legitimating use of outer space requires state investment in science. Populists who abominate the "Islamization" of Europe invest in mobilization in public space and social media. Muslim scholars who understand Europe as diaspora or a new homeland invest in institution-building and scholarly debate. Scholars of the Middle East try to convince the public as well as the academic community that the knowledge they produce about Islamic spaces is of importance.

In a second step, as a way of grasping the mutability of space and Islam, I have proposed a topological approach that leaves behind geographically or culturally defined space and focusses on the relational production of the (material, social, cultural, semiotic, economic, and political) dimensions of space. The argument was that the 
spatial expansion of Islam led to encounters between various "Others" and everchanging arrangements for these "Others" under Muslim rule. The lynchpin between the various historical examples on the previous pages was the idea that knowledge production about Islam created a trans-religious and transcultural space in which various imaginations of Islam came to circulate. The production of this multi-religious space is understood as the result of activities performed by Muslims and non-Muslims who perceive Islam, ascribe meaning to it, mark it, invest in it, or argue about it. This kind of approach does not look at isolated Muslim places and practices, but at human actions that constitute spatial relations and thereby a multi-religious topology of Islam. Some main reference points in this knowledge production-the position of Christians, Jews, and Șūfīs under Muslim rule or the anti-Trinitarian character and religious tolerance of Islam-were shared by Muslims and non-Muslims, although their meaning could strongly vary. Circulating in the global sphere over a long period of time, the notion of "Islam" has become a variegated object of global knowledge production. The continuous role that knowledge about Islam played in European debates has been at least partly forgotten or has sunken into oblivion altogether-although various actors have negotiated the idea of Islam with differing interests from the times of early Islam to the ages of Renaissance, Reformation, and Englightenment, and European colonialism to the independence of the United States.

This conception of a multi-religious space marks differences to other approaches in the studies of Islam. Although I am indebted to Shahab Ahmed (2016) and Thomas Bauer (2011) when it comes to the plural, if not contradictory, imaginations of Islam inside Muslim-majority societies, and to Cemil Aydin (2017) and Edward Said (1978) when it comes to the impact of Western perceptions of Islam especially in the nineteenth century, I detach neither Muslim negotiations of their understandings of Islam nor non-Muslim perceptions of Islam from their being situated in a cross-religious space. When Ahmed (2016) and Bauer (2011) support the idea that "contradictions" or "ambiguities" are inherent to Islam, the topological approach disagrees on three levels. Firstly, both authors do not dwell on the continuous historical transformations that can strengthen or dedifferentiate the underlying ambiguities. Secondly, they overestimate the pre-modern/modern divide that, according to them, created a modern Islam totally different from its pre-modern plural form. Thirdly, while they base the existence of Islamic contradictions/ambiguities on an intra-Islamic dynamism, they offer no place for the multi-religious diversity of Islamic landscapes-with the exception of modern Islam, whose emergence they do not explain by an intra-Islamic logic but mainly by extraIslamic factors, such as European colonialism and modernity. Although both authors try to grasp the totality of Islam, their approaches envision a kind of uniform space; even if this space is treated as consistently contradictory, this is not fully satisfying. The 
production and perception of space generally involves rugged, polycentric, dynamically changing, and hierarchical landscapes. Even given persistent Islamic ambiguities, it should be made visible that the practical effect of ambiguity was locally and historically differentiated, even in pre-modern times.

In a similar way, Aydin's (2017) thesis that "the idea of the Muslim world" resulted from nineteenth-century European-Muslim encounters that made Muslim élites adopt European ideas about themselves seems somewhat one-sided. Aydin's attempt to explain unpleasant developments of modern-violent, intolerant-understandings of Islam through the impact of Western colonialism shares with Ahmed (2016) and Bauer (2011) the ambivalent tone, since it can be read as an explanation of transcultural interconnections and power asymmetries, at best, or an exculpation, at worst.

The topological approach is also critical of the blunt rejection of "Orientalism" in the tradition of Edward Said (1978) that is premised on the spatial divide between Orient and Occident. Said dismissed the production of an imaginary Orient as a mere expression of Western domination, without considering that the production of space always incorporates boundary work and an imaginary dimension. His rejection of the Orientalist kind of image production does not acknowledge the partly positive ways in which a minority of European and American theologians, writers, scholars, and politicians engaged with Islam for various reasons (e.g. Irwin 2007), especially when trying to plead for tolerance and religious freedom. The criticism of one-sided Western image production neither recognizes circuits of knowledge production nor falsely positive, yet efficacious images of Islam.

Finally, the previous pages have shown that it has always been only a minority of non-Muslims who held a positive, or at least double-edged, view of Muhammad, the Saracens, the Turks, or Islam. Recently, Arshad et al. $(2015,18)$ have once again demonstrated, by way of a long-term analysis of New York Times headlines from 1990 to 2015, that Islam and Muslims-in contrast to Christians and Jews and a multitude of other nouns-are associated with negative terms so consistently that their image is even worse than that of cancer. ${ }^{37}$ From a historical point of view, the current prevalence of extremely negative tropes about Islam is no news and can be interpreted as the downside of Islam's global circulation as a mutable mobile, aggravated by reactions to recent acts of violence perpetrated in the name of Islam and by perceptions of problems of social cohesion in democratic societies.

37 Islam stood out as the term with the highest negative sentiment among all terms, scoring 57 percent of overall negative headlines versus 34 percent for cancer (total average: 29). Cancer also beat Islam with 17 percent of overall positive headlines versus eight (average: 14); only cocaine (seven percent) was rated lower than Islam. 
As a way of deepening the critique of one-sided-Muslim as well as non-Muslimrepresentations of Islam, this article has tried to underline the central place of Islam in European and global history as well as the multi-religious experiences in Islamic contexts and the cross-connection between both phenomena. It thus aimed to follow Coronil's (1996) critique of a historical disjunction between the producers and the objects of knowledge by underlining "the relational nature of representations of human collectivities" (Coronil 1996, 56). By treating "Islam" as a traveling, mutable mobile, my focus was not to explain that the dominance of certain imaginations and practices of Islam followed from "asymmetrical relations of power, including the power to obscure their genesis in inequality" (ibid.), since the existence of asymmetries inside and outside the territories under Muslim rule seems an obvious fact. Rather, my interest was to show that production-as well as dissemination, consumption, negotiation, destruction, and oblivion-of various imaginations of Islam created a global space. Thus, this article hopefully contributed to Coronil's critique of a historiography that presents "as the internal and separate attributes of bounded entities what are in fact historical outcomes of connected peoples" (ibid.). In this sense, the emergence of "Europe" and "Islam" as separate and antagonistic entities can also be seen as the effect not only of interrelations, but also of the circulation of ideas in a common space of knowledge production.

\section{Literature}

Abulafia, David. 2011. The Great Sea: A Human History of the Mediterranean. New York: Oxford University Press.

- - - 2012. "Aragon versus Turkey - Tirant lo Blanc and Mehmed the Conqueror. Iberia, the Crusade, and Late Medieval Chivalry." In Byzantines, Latins, and Turks in the Eastern Mediterranean World after 1150, edited by Jonathan Harris, Catherine Holmes, and Eugenia Russell, 291-312. Oxford: Oxford University Press.

Abu-Lughod, Janet. 1989. Before European Hegemony. The World System A.D. 12501350. New York.

Ágoston, Gábor. 2009. “Janissaries." In Encyclopedia of the Ottoman Empire, edited by Gábor Ágoston and Bruce Master, 296-297. New York: Facts on File.

Ahmed, Shahab. 2016. What Is Islam? The Importance of Being Islamic. Princeton, NJ.: Princeton University Press.

Al-Azmeh, Aziz. 1996. Die Islamisierung des Islams: Imaginäre Welten einer politischen Theologie. Frankfurt am Main: Campus. 
- - . 2003. "Postmodern Obscurantism and 'the Muslim Question'." Journal for the Study of Religions and Ideologies 5: 21-47.

Albrecht, Sarah. 2016. "Searching for the 'Homeland' of Islam. Concepts of Diaspora in Contemporary Islamic Discourse on Muslims in the West." Journal of Muslims in Europe 5: 106-131.

Almond, Ian. 2010. History of Islam in German Thought from Leibniz to Nietzsche. New York: Routledge.

Anthony, Sean W. 2011. "The Legend of 'Abdallāh ibn Saba' and the Date of the Umm al-Kitāb." Journal of the Royal Asiatic Society, Third Series, 21 (1): 1-30.

Arshad, Owais, Varun Setlur, and Usaid Siddiqui, Usaid. 2015: Are Muslims Collectively Responsible. A Sentiment Analysis of the New York Times. Accessed August, 15, 2018. http://416labs.com/nytandislam.

Aydin, Cemil. 2017. The Idea of the Muslim World: A Global Intellectual History. Cambridge, Mass.: Harvard University Press.

Bachmann-Medik, Doris. 2006. Cultural Turns: Neuorientierungen in den Kulturwissenschaften. Reinbeck: Rowohlt.

Baer, Marc. 2004. "The Double Bind of Race and Religion: The Conversion of the Dönme to Turkish Secular Nationalism." Comparative Studies in Society \& History 46 (4): 678-712.

- - . 2007. "An Enemy Old and New: The Dönme, Anti-Semitism, and Conspiracy Theories in the Ottoman Empire and Turkish Republic." Jewish Quarterly Review 103 (4): 523-555.

- - . 2008. Honored by the Glory of Islam: Conversion and Conquest in Ottoman Europe. New York: Oxford University Press.

-_- 2010. The Dönme: Jewish Converts, Muslim Revolutionaries, and Secular Turks. Stanford, Calif.: Stanford University Press.

Bauer, Thomas. 2011. Die Kultur der Ambiguität. Eine andere Geschichte des Islams. Berlin: Verlag der Weltreligionen.

Bashir, Shahzad. 2018. "Everlasting Doubt: Uncertainty in Islamic Representations of the Past." Archiv für Religionsgeschichte 20 (1): 25-44.

Beinhauer-Köhler, Bärbel. 2015. “Im Zwischenraum. Plurale Raumarrangements aus religionswissenschaftlicher Sicht." In Viele Religionen - ein Raum!? Analysen, Diskussionen und Konzepte, edited by Bärbel Beinhauer-Köhler, Mirko Roth, and Bernadette Schwarz-Boenneke, 55-76. Berlin: Frank \& Timme.

Bendixsen, Synnøve. 2013. The Religious Identity of Young Muslim Women in Berlin. Leiden: Brill.

Bennison, Amira K. 2007. "The Peoples of the North in the Eyes of the Muslims of Umayyad al-Andalus (711-1031)." Journal of Global History 2: 157-174. 
- - . 2010. "Almohad tawhīd and its Implications for Religious Difference." Journal of Medieval Iberian Studies 2 (2): 195-216.

Bennison, Amira K., and Maria Angeles Gallego. 2010. "Religious Minorities under the Almohads: An Introduction." Journal of Medieval Iberian Studies 2 (2): 143-154.

Berger, Maurits S. 2013. "The Third Wave: Islamization of Europe, or Europeanization of Islam?" Journal of Muslims in Europe 2: 115-136.

Biasiori, Lucio. 2018. “Islamic Roots of Machiavelli's Thought? The Prince and the Kitāb sirr al-asrār from Baghdad to Florence and Back." In Machiavelli, Islam and the East. Reorienting the Foundations of Modern Political Thought, edited by idem. and Giuseppe Marcocci, 17-36. Cham: Palgrave Macmillan.

Biasiori, Lucio, and Giuseppe Marcocci. 2018. "Introduction: Reorienting Machiavelli." In Machiavelli, Islam and the East. Reorienting the Foundations of Modern Political Thought, edited by idem., 1-13. Cham: Palgrave Macmillan.

Bietenholz, Peter G. 2009. Encounters with a Radical Erasmus. Erasmus' Work as a Source of Radical Thought in Early Modern Europe. Toronto: Toronto University Press.

Blair, Sheila. 1995. A Compendium of Chronicles. Rashid al-Din's Illustrated History of the World. London: Nour Foundation.

Bobzin, Hartmut. 1995. Der Koran im Zeitalter der Reformation. Studien zur Frühgeschichte der Arabistik und Islamkunde in Europa. Stuttgart: Franz Steiner.

Bonine, Michael E., Abbas Amant, and Michael Ezekiel Gaspar, eds. 2011. Is There a Middle East? The Evolution of a Geopolitical Concept. Stanford: Stanford University Press.

Bosworth, C.E. 2003. “Harrān.” Encyclopaedia Iranica. Accessed August, 25, 2018. http://www.iranicaonline.org/articles/harran.

Boušek, Daniel. 2011. "Polemics in the Age of Religious Persecutions: Maimonides' Attitude towards Islam." Asian and African Studies 20 (1): 46-85.

Böwering, Gerhard. 1983. "Abū Sa'īd Abī'l-Kayr." Encyclopaedia Iranica. Accessed August, 25, 2018. http://www.iranicaonline.org/articles/abu-said-fazlallah-b.

Bowman, Glenn, ed. 2012. Sharing the Sacra. The Politics and Pragmatics of Intercommunal Relations around Holy Places. New York: Berghahn Books.

Braudel, Fernand. 1979-1980. Civilisation matérielle, économie et capitalisme, XVe XVIIle siècle, 3 vols. Paris: Colin.

Braukämper, Ulrich. 2005. "Kulturkreis." In Wörterbuch der Völkerkunde, edited by Walter Hirschberg, 223-224. Berlin: Reimer.

Brubaker, Rogers, and Frederick Cooper. 2000. "Beyond 'identity'." Theory and Society 29: 1-47. 
Bruckmayr, Philipp. 2018. "Divergent processes of localization in twenty-first century Shi'ism: The Cases of Hezbollah Venezuela and Cambodia's Cham Shi'is." British Journal of Middle Eastern Studies, 45 (1): 18-38.

Bryce, Derek. 2013. "The Absence of Ottoman, Islamic Europe in Edward W. Said's Orientalism." Theory, Culture \& Society 30 (1): 99-121.

Budde, Gunilla, Sebastian Conrad, and Oliver Janz, eds. 2006. Transnationale Geschichte. Themen, Tendenzen und Theorien. Göttingen: Vandenhoeck \& Ruprecht.

Bulliet, Richard W. 1979. Conversion to Islam in the Medieval Period: An Essay in Quantitative History. Cambridge, Mass.: Cambridge University Press.

Burke III, Edmund. 2009. "Islam at the Center: Technological Complexes and the Roots of Modernity." Journal of World History 20 (2): 165-186.

-_- 2012. "Toward a Comparative History of the Mediterranean, 1750-1919." Journal of World History 23 (4): 907-939.

Clancy-Smith, Julia. 2010. Mediterraneans: North Africa and Europe in the Age of Migration, 1800-1900. Berkeley: University of California Press.

Clarence-Smith, William G. 2007. "Editorial - Islamic history as global history." Journal of Global History 2: 131-134.

Conermann, Stephan, ed. 1998. Der Indische Ozean in historischer Perspektive. Hamburg: E.B.-Verlag.

- - , ed. 2017. Muslim-Jewish Relations in the Middle Islamic Period. Jews in the Ayyubid and Mamluk Sultanates (1171-1517). Bonn: Bonn University Press.

Considine, Craig. 2018. Muslims in America. Examining the Facts. Santa Barbara: ABCClio.

Corcos, David. 2010. "The Nature of the Almohad Rulers' Treatment of the Jews." Journal of Medieval Iberian Studies 2 (2): 259-285.

Coronil, Fernando. 1996. “Beyond Occidentalism: Toward Non-Imperial Geohistorical Categories." Cultural Anthroplogy 11 (1): 51-87.

Courbage, Youssef and Philippe Fargues. 1997. Christians and Jews under Islam. London: I.B. Tauris.

Couroucli, Maria. 2012. "Sharing Sacred Places - A Mediterranean Tradition." In Sharing Sacred Spaces in the Mediterranean: Christians, Muslims, and Jews at Shrines and Sanctuaries, edited by Dionigi Albera and Maria Couroucli, 1-9. Bloomington: Indiana University Press.

Crone, Patricia. 1991. „Mawlā.“ In The Encyclopaedia of Islam, 2nd ed, vol. VI, edited by P. Bearman, Th. Bianquis, C.E. Bosworth, E. van Donzel, and W.P. Heinrichs, 874a-882b. Leiden: Brill. 
Cuffel, Alexandra. 2003. “'Henceforward all generations will call me blessed': Medieval Christian Tales of Non-Christian Marian Veneration." Mediterranean Studies 12: 37-60.

- - . 2005. “From Practice to Polemic: Shared Saints and Festivals as 'Women's Religion' in the Medieval Mediterranean." Bulletin of the School of Oriental and African Studies 68 (3): 401-419.

Curtis IV, Edward E. 2009. Muslims in America. A Short History. Oxford: Oxford University Press.

Davis, Natalie Z. 2006. Trickster Travels: A Sixteenth-Century Muslim between Worlds. New York: Hill and Wang.

Davison, Roderic H. 1960. "Where Is the Middle East?" Foreign Affairs 38 (4): 665-675. Den Boer, Harm, and Pier Mattia Tommasino (2014): "Reading the Qur'ān in the $17^{\text {th }}$ Century Sephardi Community of Amsterdam." Al-Qantara 35 (2): 461-491.

Determann, Jörg Matthias. 2018. Space Science and the Arab World. Astronauts, Observatories and Nationalism in the Middle East. London: I.B. Tauris.

Deutsch, Jan-Georg, and Brigitte Reinwald, eds. 2002. Space on the Move: Transformations of the Indian Ocean Seascape in the Nineteenth and Twentieth Century. Berlin: Schwarz.

Dörfler, Thomas. 2010. "Raumtheorie nach dem spatial turn." In Gentrification in Prenzlauer Berg? Milieuwandel eines Berliner Sozialraums seit 1989, edited by Thomas Dörfler, 16-89, Bielefeld: transcript.

Dressler, Markus. 2005. "Inventing Orthodoxy: Competing Claims for Authority and Legitimacy in the Ottoman-Safavid Conflict." In Legitimizing the Order. The Ottoman Rhetoric of State Power, edited by Hakan T. Karateke and Maurus Reinkowski, 151-173. Leiden: Brill.

- - . 2010. "How to Conceptualize Inner-Islamic Plurality/Difference: 'Heterodoxy' and 'Syncretism' in the Writings of Mehmet F. Köprülü (1890-1966)." British Journal of Middle Eastern Studies 37 (3): 241-260.

- - . 2013. Writing Religion. The Making of Turkish Alevism. New York: Oxford University Press.

Eaton, Richard M. 1993. "Islamic History as Global History." In Islamic and European Expansion: The Forging of a Global Order, edited by Michael Adas, 1-35. Philadelphia: Temple University Press.

Ehmann, Johannes. 1999. Confutatio Alcorani (1300)/Verlegung des Alcoran (1542): Kommentierte lateinisch-deutsche Textausgabe. Wiesbaden: Echter-Verlag.

-_- 2008. Luther, Türken und Islam: eine Untersuchung zum Türken- und Islambild Martin Luthers (1515-1546). Gütersloh: Gütersloher Verlagshaus. 
Elmarsafy, Ziad. 2009. The Enlightenment Qur'an: The Politics of Translation and the Construction of Islam. Oxford: One World.

Elverskog, Johan. 2010. Buddhism and Islam on the Silk Road. Philadelphia: University of Pennsylvania Press.

Ende, Werner. 1977. Arabische Nation und islamische Geschichte. Die Umayyaden im Urteil arabischer Autoren des 20. Jahrhunderts. Beirut: Steiner.

Escher, Anton. 2016. "Geographie des islamischen Raumes." In Der Islam. Einheit und Vielfalt einer Weltreligion, edited by Rainer Brunner, 11-43. Stuttgart: Kohlhammer.

Esposito, John, ed. 2009. The Oxford Encyclopedia of the Islamic World. New York: Oxford University Press.

Fakhry, Majid. 2001. Averroes (Ibn Rushd): His Life, Works, and Influence. Oxford: Oneworld.

Fenton, Paul B. 2017. "Sufis and Jews in Mamluk Egypt." In Conerman 2017, 41-62.

Fick, Monika. 2017. "Lessings Nathan der Weise und das Bild vom Orient und Islam in Theatertexten aus der zweiten Hälfte des 18. Jahrhunderts." In Goethezeitportal. February 15, 2017. http://www.goethezeitportal.de/db/wiss/ lessing/fick_orient.pdf.

Figl, Johann. 2008. Nietzsche und die Religionen: Transkulturelle Perspektiven seines Bildungs- und Denkweges. Berlin: De Gruyter.

Firges, Pascal. 2017. French Revolutionaries in the Ottoman Empire: Diplomacy, Political Culture, and the Limiting of Universal Revolution, 1792-1798. Oxford: Oxford University Press.

Fischer, Niels. 2008. "Islamic Religious Practice in Outer Space." ISIM Review 22: 39.

Fowden, Elizabeth Key. 1999. "Sharing Holy Places." Common Knowledge 8 (1): 124146.

Frank, André Gunder. 1998. ReOrient: Global Economy in the Asia Age. Berkely: University of California Press.

Frankopan, Peter. 2015. The Silk Roads. A New History of the World. London: Bloomsbury. Freitag, Ulrike. 2003. Indian Ocean Migrants and State Formation in Hadhramaut. Leiden: Brill.

Freitag, Ulrike, and Achim von Oppen. 2010. “'Translocality'. An Approach to Connection and Transfer in Regional Studies. Introduction." In Translocality. The Study of Globalising Processes from a Southern Perspective, edited by Ulrike Freitag and Achim von Oppen, 1-24. Leiden: Brill.

Frobenius, Leo. 1898. Der Ursprung der afrikanischen Kulturen. Berlin: Borntraeger.

Garcia, Humberto. 2012. Islam and the English Enlightenment. Baltimore: Johns Hopkins University Press. 
Gebauer, Matthias, and Shadia Husseini de Araújo. 2016. “Islamic Shores Along the Black Atlantic. Analysing Black and Muslim Countercultures in Post-Colonial Societies." Journal of Muslims in Europe 5: 11-37.

Gerbner, Katherine. 2007. '“We are against the Traffik of Men-Body.' The Germantown Quaker Protest of 1688 and the Origins of American Abolitionism." Pennsylvania History 74 (2): 149-172.

Goitein, Shlomo D. 1967-1988. A Mediterranean Society. The Jewish Communities of the Arab World as portrayed in the Documents of the Cairo Geniza, 6 vols. Berkeley: University of California Press.

Goldziher, Iganz. 1903. "Über den Einfluss des Buddhismus auf den Islam," übersetzt und kommentiert von Markus Groß. Accessed August 25, 2018. http:// inarah.de/sammelbaende-und-artikel/inarah-band-4/ueber-den-einfluss-desbuddhismus-auf-den-islam.

Gordon-Reed, Annette. 2008. The Hemingses of Monticello. New York: Norton.

Graf, Tobias P. 2017. The Sultan's Renegades. Christian-European Converts to Islam and the Making of the Ottoman Elite, 1575-1610. Oxford: Oxford University Press.

Graham-Harrison, Emma, and Joshua Surtees. 2018. “Trinidad's Jihadis: How Tiny Nation Became ISIS Recruiting Ground. The Caribbean nation has one of the world's highest Isis volunteer rates - and most don't come back." Guardian. February 2, 2018. https://www.theguardian.com/world/2018/feb/02/trinidadjihadis-isis-tobago-tariq-abdul-haqq.

Green, Nile. 2014. "Rethinking the 'Middle East' after the Oceanic Turn." Comparative Studies of South Asia, Africa and the Middle East 34 (3): 556-564.

Green, Tamara M. 1992. The City of the Moon God, Leiden: Brill.

Griffel, Frank. 1999. "Toleranzkonzepte im Islam und ihr Einfluß auf Jean Bodins Colloquium Haptaplomeres." In Bodinus Polymeres. Neue Studien zu Jean Bodins Spätwerk, edited by Ralph Häfner, 119-144. Wiesbaden: Harrassowitz.

- - . 2017. "Contradictions and Lots of Ambiguity: Two New Perspectives on Premodern (and Postclassical) Islamic Societies. Review Article of Shahab Ahmed's 'What is Islam?' and Thomas Bauer's 'Kultur der Ambiguität'." Bustan: The Middle East Book Review 8 (1): 1-21.

Gruber, Christiane, and Avinoam Shalem. 2014. "Introduction: Images of the Prophet Muhammad in a Global Context." In The Image of the Prophet between Ideal and Ideology. A Scholarly Investigation, edited by Christian Gruber and Avinoam Shalem, 1-9. Berlin: De Gruyter.

Guessoum, Nidhal. 2013. "Time for an Arab astronomy renaissance." Nature 498: 161164. 
Gürkan, Emrah Safa. 2010. "Christian Allies of the Ottoman Empire." European History Online (EGO), published by the Institute of European History (IEG), Mainz. December 03, 2010. http://www.ieg-ego.eu/gurkane-2010-en.

Günzel, Stephan. 2017. Raum. Eine kulturwissenschaftliche Einführung. Bielefeld: transcript.

Hacısalihoğlu, Mehmet. 2007. "Inclusion and Exclusion: Conscription in the Ottoman Empire." Journal of Modern European History 5 (2): 264-286.

Hadjikyriacou, Antonis. 2016a. "The Province Goes to the Center. The Case of Hadjiyorgakis Kornesios, Dragoman of Cyprus." In Living in the Ottoman Realm. Empire and Identity, 13th to 20th Centuries, edited by Christine IsomVerhaaren and Kent F. Schull, 239-251. Bloomington: Indiana University Press.

- - . 2016b. "The Ottomanization of Cyprus: Towards a Spatial Imagination Beyond the Center-Province Binary." Journal of Mediterranean Studies 25 (2): 81-96.

Hashas, Mohammed. 2013. On the Idea of European Islam. Voices of Perpetual Modernity, Rome. Accessed August, 15, 2018. https://eprints.luiss.it/1237/1/20130603hashas.pdf

Hasluck, Frederick W. 1929. Christianity and Islam under the Sultans, 2 vols. Oxford: At the Clarendon Press.

Hasse, Dag N. 2013. "Die Überlieferung arabischer Philosophie im lateinischen Westen." In Islamische Philosophie im Mittelalter. Ein Handbuch, edited by Heidrun Eichner, Matthias Perkams, and Christian Schäfer, 377-400. Darmstadt: Wissenschaftliche Buchgesellschaft.

Hayden, Robert M. 2002. "Antagonistic Tolerance. Competitive Sharing of Religious Sites in South Asia and the Balkans." Current Anthropology 43 (2): 205-231.

Helmedach, Andreas, Markus Koller, Konrad Petrovszky, and Stefan Rohdewald. 2013. "Das osmanische Europa als Gegenstand der Forschung." In Das osmanische Europa: Methoden und Perspektiven der Frühneuzeitforschung zu Südosteuropa, edited by Andreas Helmedach, Markus Koller, Konrad Petrovszky, and Stefan Rohdewald, 9-23. Leipzig: Eudora-Verlag.

Hillenbrand, Robert. 2014. "Muhammad as Warrior Prophet. Images from the World History of Rashid al-Din." In The Image of the Prophet between Ideal and Ideology. A Scholarly Investigation, edited by Christiane Gruber and Avinoam Shalem, 65-75. Berlin: De Gruyter.

Hodgson, Marshal G.S. 1974. The Venture of Islam, 3 vols. Chicago: Chicago University Press.

--_. 1993. Rethinking World History. Essays on Europe, Islam, and World History, edited by Edmund Burke III. Cambridge: Cambridge University Press. 
Holmes, Catherine. 2012. "Introduction." In Byzantines, Latins, and Turks in the Eastern Mediterranean World after 1150, edited by Jonathan Harris, Catherine Holmes, and Eugenia Russell, 1-29. Oxford: Oxford University Press.

Horden, Peregrine, and Nicolas Purcell. 2000. The Corrupting Sea: A Study of Mediterranean History. Oxford: Blackwell.

Houghton, H.A.G. 2016. The Latin New Testament: A Guide to its Early History, Texts, and Manuscripts. Oxford Scholarship Online. DOI: 10.1093/acprof:0 so/9780198744733.001.0001.

Hoyland, Robert G. 2011. "The Jews of the Hijaz in the Qur'ān and in their Inscriptions." In New Perspectives on the Qur'ān. The Qur'ān in its Historical Context 2, edited by Gabriel S. Reynolds, 91-116. London: Routledge.

Huntington, Samuel P. 1996. The Clash of Civilizations and the Remaking of World Order. New York: Simon \& Schuster.

Husayn, Fālih. 2012. "The Participation of Non-Arab Elements in the Umayyad Army and Administration. Translated by Emran El-Badawi and Fred M. Donner." In The Articulation of Early Islamic State Structures, edited by Fred M. Donner, 265289. Surrey: Ashgate.

Ibn 'Arabī, Muḥyī al-Dīn. 1911. The Tarjūmān al-Ashwāq, A Collection of Mystical Odes by Muhyî'ddīn ibn al-'Arabī, edited and translated by Richard A. Nicholson, London. Accessed August, 20, 2018. https://www.sacred-texts.com/isl/taa/ index.htm.

Irwin, Robert. 2007. For Lust of Knowing: The Orientalists and their Enemies. London: Penguin Books.

Jackson, Peter. 2017. The Mongols and the Islamic World. From Conquest to Conversion. New Haven: Yale University.

Jankowiak, Marek. 2017. "What Does the Slave Trade in the Saqaliba Tell US about Early Islamic Slavery?" International Journal of Middle East Studies 49: 169-172.

Jaschok, Maria, and Shui Jingjun. 2000. The History of Women's Mosques in Chinese Islam. A Mosque of Their Own. Richmond: Curzon.

Kafadar, Cemal. 1995. Between Two Worlds: The Construction of the Ottoman State. Berkeley, Calif: University of California Press.

Kaplony, Andreas. 2016. “Die Arabisierung der frühislamischen Verwaltung SyrienPalästinas und Ägyptens im Spiegel der zweisprachigen griechisch-arabischen Dokumente (550-750): ein Plädoyer für einen regionalen Ansatz." In Denkraum Spätantike. Reflexionen von Antiken im Umfeld des Koran, edited by Nora Schmidt, Nora K. Schmid, and Angelika Neuwirth, 387-404. Wiesbaden: Harrassowitz. 
Kavas, Ahmet. 2007. "Ottoman Empire's Relations with Southern Africa." Journal of the Faculty of Divinity of Ankara University 48 (2): 11-20.

Khalidi, Rashid. 1998. "The 'Middle East' as a Framework of Analysis: Re-Mapping a Region in the Era of Globalization." Comparative Studies of South Asia, Africa and the Middle East 17 (1): 74-80.

Kidd, Thomas S. 2003. "'Is It Worse to Follow Mahomet than the Devil?' Early American Uses of Islam." Church History 72 (4): 766-790.

Kieser, Hans-Lukas. 2001. "Muslim Heterodoxy and Protestant Utopia. The Interactions between Alevis and Missionaries in Ottoman Anatolia." Die Welt des Islams 41 (1): 89-111.

König, Daniel G. 2010. “Muslim Perception(s) of 'Latin Christianity': Methodological Reflections and a Reevaluation." In Labeling the Religious Self and Others: Reciprocal Perceptions of Christians, Muslims, Hindus, Buddhists, and Confucians in Medieval and Early Modern Times, edited by Hans Martin Krämer et al., 18-42. Comparativ. Zeitschrift für Globalgeschichte und vergleichende Gesellschaftsforschung.

-_- 2017. "Rezension zu: Bruce, Scott G.: Cluny and the Muslims of La Garde-Freinet. Hagiography and the Problem of Islam in Medieval Europe." H-Soz-Kult. April 26, 2017. https://www.hsozkult.de/publicationreview/id/rezbuecher-26136.

Knott, Kim. 2005. "Spatial theory and method for the study of religion." Temenos 41 (2): 153-184.

- - . 2009. "From locality to location and back again: A spatial journey in the study of religion," Religion 39: 154-60.

Konrad, Felix. 2010. "Soziale Mobilität europäischer Renegaten im frühneuzeitlichen Osmanischen Reich." In Religion und Mobilität. Zum Verhältnis von raumbezogener Mobilität und religiöser Identitätsbildung im frühneuzeitlichen Europa, edited by Henning P. Jürgens and Thomas Weller, 213-234. Göttingen: Vandenhoeck \& Ruprecht.

-_- 2011. "From the 'Turkish Menace' to Exoticism and Orientalism: Islam as Antithesis of Europe (1453-1914)?" European History Online (EGO), edited by the Institute of European History (IEG). March 14, 2011. http://www.ieg-ego.eu/ konradf-2010-en.

Koren, Marina. 2018. "The Middle East's Growing Space Ambitions." The Atlantic. June 4, 2018. https://www.theatlantic.com/science/archive/2018/06/middle-eastspace-ambitions/561776.

Kramer, Martin. 1999. "Introduction." In The Jewish Discovery of Islam. Studies in Honor of Bernard Lewis, edited by Martin Kramer, 1-48. Tel Aviv: Moshe Dayan Center of Middle Eastern and African Studies. 
Kreyenbroek, Philip G. 1995. Yezidism - Its Background, Observances and Textual Tradition. Lewiston, NY: Edwin Mellen Press.

- - . 2005. "Religious Minorities in the Middle East and Transformation of Rituals in the Context of Migration." In Migration und Ritualtransfer: Religiöse Praxis der Aleviten, Jesiden und Nusairier zwischen Vorderem Orient und Westeuropa, edited by Robert Langer, Raoul Motika, and Michael Ursinus, 31-50. Frankfurt am Main: Peter Lang.

Krstić, Tijana. 2011. Contested Conversions to Islam: Narratives of Religious Change in the Early Modern Ottoman Empire. Stanford, Calif.: Stanford University Press.

-_- 2015. "Islam and Muslims in Europe." In The Oxford Handbook of Early European Modern History, 1350-1750: Volume I: Peoples and Place, edited by Hamish Scott 670-693. Oxford: University Press.

Kügelgen, Anke von. 1994. Averroes und die arabische Moderne. Ansätze zu einer Neubegründung des Rationalismus im Islam. Leiden: Brill.

- - . 2010. "Muslimische Theologen und Philosophen im Wett- und Widerstreit um die Ratio - Ein Thesenpapier zum Diktum der 'Vernunftreligion' Islam im 11.14. Jahrhundert." Asiatische Studien 64 (3): 601-648.

Kuschel, Karl-Josef. 2011. Im Ringen um den wahren Ring: Lessings "Nathan der Weise“ - eine Herausforderung der Religionen. Ostfildern: Patmos.

Lafi, Nora. 2014. "The Eighteenth Century in the Arab Provinces of the Ottoman Empire: Perspectives for a Global History." In Cultural Transfer, Encounters and Connections in the Global 18th Century, edited by Matthias Middell, 231-260. Leipzig: Leipziger Universitätsverlag.

Lang, Isabel. 2015. Intertextualität als hermeneutischer Zugang zur Auslegung des Korans. Eine Betrachtung am Beispiel der Verwendung von Isrā'īīyāt in der Rezeption der Davidserzählung in Sure 38: 21-25. Berlin: Logos.

Langer, Robert. 2010. “Yezidism between Scholarly Literature and Actual Practice: From 'Heterodox' Islam and 'Syncretism' to the Formation of a Transnational Yezidi 'Orthodoxy'." British Journal of Middle Eastern Studies 37 (3): 393-403.

Langer, Robert, and Udo Simon. 2008. "The Dynamics of Orthodoxy and Heterodoxy. Dealing with Divergence in Muslim Discourses and Islamic Studies." Die Welt des Islams 48 (3/4): 273-288.

Langer, Robert, and Benjamin Weineck. 2017. “Shiite 'Communities of Practice' in Germany. Researching Multi-Local, Heterogeneous Actors in Transnational Space." Journal of Muslims in Europe 6: 216-240.

Langer, Robert, Raoul Motika, and Michael Ursinus, eds. 2005. Migration und Ritualtransfer: Religiöse Praxis der Aleviten, Jesiden und Nusairier zwischen Vorderem Orient und Westeuropa. Frankfurt am Main: Peter Lang. 
Lapidus, Ira. 1989. A History of Islamic Societies. Cambridge: Cambridge University Press.

Lawton, John, and Patricia Moody. 1986. "A Prince in Space." Aramco World (January/ February). Accessed July, 12, 2018. http://archive.aramcoworld.com/ issue/198601/a.prince.in.space.htm.

Lecker, Michael. 1985. "Muḥammad at Medina: A Geographical Approach." Jerusalem Studies in Arabic and Islam 6: 29-62.

-_- 1995a: Muslims, Jews, and Pagans. Studies on Early Islamic Medina. Leiden: Brill.

- - . 1995b. "On Arabs of the Banū Kilāb Executed Together with the Jewish Banū Qurayza." Jerusalem Studies in Arabic and Islam 19: 66-72.

- - - 2012. "Constitution of Medina." In Encyclopaedia of Islam³, edited by Kate Fleet, Gudrun Krämer, Denis Matringe, John Nawas, and Everett Rowson, 100-104. Leiden: Brill.

- - . 2016. "Were There Female Relatives of the Prophet Muhammad among the Besieged Qurayẓa." Journal of the American Oriental Society 136 (2): 397-404.

-_- 2017. "The Monotheistic Cousins of Muḥammad's Wife Khadīja." Der Islam 94 (2): 363-384.

Lefebvre, Henri. 1974. La production de l'espace. Paris: Anthropos.

Lewis, Cathleen S. 2013. "Muslims in Space: Observing Religious Rites in a New Environment." Astropolitics 11 (1-2): 108-115.

Lipton, Gregory A. 2011. "Secular Sufism: Neoliberalism, Ethnoracism, and the Reformation of the Muslim Other." Muslim World 101: 427-440.

- - . 2017. "De-Semitizing Ibn 'Arabī: Aryanism and the Schuonian Discourse of Religious Authenticity." Numen 64: 258-293.

-_- 2018. Rethinking Ibn 'Arabi. New York: Oxford University Press.

Loimeier, Roman. 2009. "Editorial" (Islam in Contemporary West Africa: Literature, Orality and Law). Die Welt des Islams 49 (3/4): 287-298.

- - . 2013. "Is There an 'African' Islam." In Muslim Societies in Africa: A Historical Anthropology, by Roman Loimeier, 11-34. Bloomington, Ind.: Indian University Press.

Lorcin, Patricia M.E., and Todd Shepard. 2016. French Mediterraneans. Transnational and Imperial Histories. Lincoln and London: University of Nebraska Press.

Löw, Martina. 2001. Raumsoziologie. Frankfurt am Main: Suhrkamp.

Lüling, Günter. 1993. Über den Urkoran. Ansätze zur Rekonstruktion der vorislamischchristlichen Strophenlieder im Koran. Erlangen: Verlagsbuchhandlung H. Lüling. Meggitt, Justin J. 2013. Early Quakers and Islam. Slavery, Apocalyptic and ChristianMuslim Encounters in the Seventeenth Century. Uppsala: Swedish Science Press. 
Malcolm, Noel. 2006. "Jean Bodin and the Authorship of the Colloquium Heptaplomeres." Journal of the Warburg and Courtauld Institutes 69: 95-150.

Marcotte, Roxanne D. 2001. "Suhrawardi al-Maqtul, The Martyr of Aleppo." Al-Qantara, 22 (2): 395-419.

Massignon, Louis. 1975. La passion de Husayn Ibn Mansûr Hallâj : martyr mystique de I'Islam exécuté à Bagdad le 26 mars 922 ; étude d'histoire religieuse. 4 volumes. Paris: Gallimard.

Masters, Bruce. 2001. Christians and Jews in the Ottoman Arab World: The Roots of Sectarianism. Cambridge: Cambridge University Press.

Mastnak, Tomaž. 1994. "Fictions in Political Thought. Las Casas, Sepúlveda, the Indians, and the Turks." Filozofski Vestnik 15: 127-149.

Masuzawa, Tomoko. 2005. The Invention of World Religions: Or, How European Universalism Was Preserved in the Langue of Pluralism. Chicago: University of Chicago Press.

McCormick, Michael. 2001. Origins of European Economy. Communications and Commerce, $A D$ 300-900. Cambridge: Cambridge University Press.

McDonald, Grantley. 2017. "The Johannine Comma from Erasmus to Westminster." In Scriptural Authority and Biblical Criticism in the Dutch Golden Age: God's Word Questioned, edited by Dirk van Miert, Henk Nellen, Piet Steenbakkers, and Jetze Touber. Oxford Scholarship Online. DOI:10.1093/oso/9780198806837.003.0003.

Mielke, Katja, and Anna-Katharina Hornidge. 2014. “Crossroads Studies: From Spatial Containers to Interactions in Differentiated Spatialites. 'Area Studies'-Discussion Paper of the Research Network Crossroads Asia." Crossroads Asia Working Paper Series. Accessed December 15, 2018. https://d-nb.info/1112962972/34.

Mojaddedi, Jawid. 2013. "Hallāj, Abū I-Moḡit Hosayn." Encyclopaedia Iranica. Accessed August, 25, 2018. http://www.iranicaonline.org/articles/hallaj-1.

Mommsen, Katharina. 2001. Goethe und der Islam. Frankfurt am Main: Insel.

Munt, Harry. 2015. “'No two religions': Non-Muslims in the early Islamic Ḥijāz." Bulletin of SOAS 78 (2): 249-269.

Nawas, John A. 1994. "Reexamination of Three Current Explanations for al-Ma'mun's Introduction of the Mihna." International Journal of Middle East Studies 26 (4): 615-629.

Noth, Albrecht. 1978. “Möglichkeiten und Grenzen islamischer Toleranz." Saeculum 29: 190-204.

Nicholson, Reynold A. 1914: The Mystics of Islam. London: Bell and Sons.

O'Fahey, R.S., and Bernd Radtke. 1993. "Neo-Sufism Reconsidered." Der Islam 70: 5287. 
Onnudottir, Helena, Adam Possamai, and Bryan Turner. 2012. "Islam and Indigenous Populations in Australia and New Zeeland." In Muslims in the West and the Challenges of Belonging, edited by Fethi Mansouri and Vince Marotta, 60-86. Carlton, Vic.: Melbourne University Press.

Østebø, Terje. 2012. Localising Salafism. Religious Change among Oromo Muslims in Bale, Ethiopia. Leiden: Brill.

Pagden, Anthony. 1987. "Dispossessing the Barbarian: The Language of Spanish Thomism and the Debate over the Property Rights of the American Indians." In The Languages of Political Theory in Early-Modern Europe, edited by Anthony Pagden, 79-98. Cambridge: Cambridge University Press.

Peirce, Leslie P. 1993. The Imperial Harem: Women and Sovereignty in the Ottoman Empire. New York: Oxford University Press.

Peleikis, Anja. 2001. "Shifting Identities, Reconstructing Boundaries. The Case of a Multi-Confessional Locality in Post-War Lebanon." Die Welt des Islams 41 (3): 400-429.

Pink, Johanna. 2016. "Islam und Nichtmuslime." In Islam. Einheit und Vielfalt einer Weltreligion, edited by Rainer Brunner, 481-500. Stuttgart: Kohlhammer.

Poppe, Patrick. 2014. "Radix Turcorum, radix Mahumeti? Entstehungs- und Herkunftsdiskurse über den Islam im Kontext des Falls von Konstantinopel (1453)." In Die Entstehung einer Weltreligion III. Die heilige Stadt Mekka - eine literarische Fiktion (Inârah-Sammelband 7), edited by Markus Groß and KarlHeinz Ohlig, 392-420. Berlin: Schiler.

Pratt, Mary L. 1991: “Arts of the Contact Zone." Profession 91: 33-40.

Radtke, Bernd. 1994. "Warum ist der Sufi orthodox?" Der Islam 71: 302-307.

Ralston, Joshua. 2017. "Islam as Christian Trope: The Place and Function of Islam in Reformed Dogmatic Theology." The Muslim World 107: 754-776.

Reichmuth, Stefan. 2000. “'Netzwerk' und 'Weltsystem'. Konzepte zur neuzeitlichen 'Islamischen Welt' und ihrer Transformation." In Die islamische Welt als Netzwerk. Möglichkeiten und Grenzen des Netzwerkansatzes im islamischen Kontext, edited by Roman Loimeier, 53-86. Würzburg: Ergon.

Reinkowski, Maurus. 2013. “Keine Kryptoreligion, aber doch kryptoreligiös. Zur Frage einer realen Existenz von Kryptojuden und Kryptochristen im islamisch überprägten Mittelmeerraum und Nahen Osten." In Konfessionelle Ambiguität. Uneindeutigkeit und Verstellung als religiöse Praxis in der Frühen Neuzeit, edited by Andreas Pietsch and Barbara Stollberg-Rilinger, 75-98. Gütersloh: Gütersloher Verlagshaus.

-_- 2017. “Ein neuer Naher Osten? Zur realen Krise eines epistemischen Systems.” Leviathan 31: 95-113. 
Rudolph, Ulrich. 1994. "Nikolaus von Kues und der Dialog mit dem Islam." Der Islam 71: 95-108.

Said, Edward. 1978. Orientalism. New York: Pantheon Books.

Saviello, Alberto. 2015. Imaginationen des Islam: Bildliche Darstellungen des Propheten Mohammed im westeuropäischen Buchdruck bis ins 19. Jahrhundert. Berlin: De Gruyter.

Scharbrodt, Oliver. 2018. "A Minority within a Minority?: The Complexity and Multilocality of Transnational Twelver Shia Networks in Britain." Contemporary Islam. November 8, 2018. https://doi.org/10.1007/s11562-018-0431-0.

Schölch, Alexander. 1975. "Wirtschaftliche Durchdringung und politische Kontrolle durch die europäischen Mächte im Osmanischen Reich (Konstantinopel, Kairo, Tunis)." Geschichte und Gesellschaft 1: 404-446.

Serrano Ruano, Delfina. 2010. “Explicit Cruelty, Implicit Compassion: Judaism, Forced Conversions and the Genealogy of the Banū Rushd." Journal of Medieval Iberian Studies 2 (2): 217-233.

Sharkey, Heather. 2017. A History of Muslims, Jews, and Christians in the Middle East. Cambridge: Cambridge University Press.

Simonsohn, Uriel. 2017. "Communal Boundaries Reconsidered. Jews and Christians Appealing to Muslim Authorities in the Medieval Near East." Jewish Studies Quarterly 14 (4): 328-363.

Spellberg, Denise. 2006. "Could a Muslim be President? An Eighteenth-Century Constitutional Debate." Eighteenth-Century Studies 39 (4): 485-506.

- - . 2013. Thomas Jefferson's Qur'an: Islam and the Founders. New York: Vintage Books.

Spivak, Gayatri C. 1993. "Can the Subaltern Speak?" In Colonial Discourse and PostColonial Theory: A Reader, edited by Laura Chrisman and Patrick Williams, 66111. New York: Harvester Wheatsheaf.

Stewart. 2008. "The Ottoman Execution of Zayn al-Dīn al-'Āmilī." Die Welt des Islams 48 (3): 289-347.

Svanberg, Ingvar, and David Westerlund, eds. 2016. Muslim Tatar Minorities in the Baltic Sea Region. Leiden: Brill 2016.

Terzioğlu, Derin. 2013. “How to Conceptualize Ottoman Sunnitization: A Historiographical Discussion." Turcica 44: 301-338.

Tolan, John. 1996. "Anti-Hagiography: Embrico of Mainz's Vita Mahumeti." Journal of Medieval History 22 (1): 25-41.

Tolan, John, Gilles Veinstein, and Henry Laurens. 2012. "General Introduction." In Europe and the Islamic World, edited by Henry Laurens, John Tolan, and Gilles Veinstein, 12-17. Princeton: Princeton University Press. 
Tommasino, Pieter Mattia. 2018. "Roman Prophet or Muslim Caesar: Muhammad the Lawgiver Before and After Machiavelli." In Machiavelli, Islam and the East. Reorienting the Foundations of Modern Political Thought, edited by Lucio Biasiori and Giuseppe Marcocci, 79-103. Cham: Palgrave Macmillan.

Truschke, Audrey. 2018. "The Power of the Islamic Sword in Narrating the Death of Indian Buddhism." History of Religions 57 (4): 406-435.

United Nations. 2018. "The UN Regional Commissions." Accessed August 14, 2018. http://www.regionalcommissions.org/about/the-regional-commissions.

Unwin, Tim. 2000. "A Waste of Space? Towards a Critique of the Social Production of Space..." Transactions of the Institute of British Geographers 25 (1): 11- 29.

Vajda, G. 1978: "Isrā'îlīyāt." The Encyclopaedia of Islam, 2nd ed., vol. IV, edited by P. Bearman, Th. Bianquis, C.E. Bosworth, E. van Donzel, and W.P. Heinrichs, 211b-212b. Leiden: Brill.

Van de Kamp, Linda. 2016. "Introduction: Religious Circulation in Transatlantic Africa." African Diaspora 9: 1-13.

Van Ess, Josef. 1999. "Sufism and Its Opponents. Reflections on Topoi, Tribulations, and Transformations." In Islamic Mysticism Contested. Thirteen Centuries of Controversies and Polemics, edited by Frederick de Jong and Bernd Radtke, 22-44. Leiden: Brill.

-_- 2011. DerEine und das Andere. Beobachtungen an islamischen häresiographischen Texten, 2 vols. Berlin/New York: De Gruyter.

Vaziri, Mostafa. 2015. Rumi and Shams' Silent Rebellion. Parallels with Vedanta, Buddhism, and Shaivism. Basingstoke: Palgrave Macmillan.

Versteegh, Kees. 1990. "The Arab Presence in France and Switzerland in the 10th Century." Arabica 37 (3): 259-388.

Vogel, Christian. 2016. “Produkt unorganisierter Expansion? Die Berber-Enklave Fraxinetum." In Transkulturelle Verflechtung. Mediävistische Perspektiven, edited by Georg Christ et al., 197-202. Göttingen: Universitätsverlag Göttingen.

Von Oppen, Achim. 2001. "The Making and Unmaking of Boundaries in the Islamic World: Introduction." Die Welt des Islams 41 (3): 277-286.

Voll, John. 1994. "Islam as a Special World-System." Journal of World History 5 (2): 213226.

Waardenburg, Jacques, ed. 1999. Muslim Perceptions of Other Religion. A Historical Survey. Oxford: Oxford University Press.

-- - 2004. "Muslim Studies of Other Religions: The Medieval Period." In Muslims and Others in Early Islamic Society, edited by Robert Hoyland, 211-240. Aldershot: Ashgate. 
Wallerstein, Immanuel. 1980-1989. The Modern World-System, 3 vols. New York: Academic Press.

Weatherford, Jack M. 2005. Genghis Khan and the Making of the Modern World. New York: Crown.

Welsch, Wolfgang. 2017. Transkulturalität. Realität - Geschichte - Aufgabe. Wien: new academic press.

Weltecke, Dorothea. 2012. “Multireligiöse Loca Sancta und die mächtigen Heiligen der Christen." Der Islam 88 (1): 73-95.

Wild, Stefan. 1994. “'Die schauerliche Öde des heiligen Buches'. Westliche Wertungen des koranischen Stils." In Gott ist schön und er liebt die Schönheit. Festschrift für Annemarie Schimmel zum 7. April 1992 dargebracht von Schülern, Freunden und Kollegen, edited by Alma Giese and J. Christoph, 429-447. Bern: Peter Lang. Würsch, Renate. 2013. "Der Koran und seine Rezeption." Das Mittelalter 18 (1): 27-45. Yusuf, Imtiyaz. 2010. "Islam and Buddhism Relations from Balkh to Bangkok and Tokyo." In The Muslim World 100, 177-186.

-_- 2013. "Islam and Buddhism," In The Wiley-Blackwell Companion to InterReligious Dialogue, edited by Catherine Cornille, 360-375. Chichester: Wiley Blackwell.

Zilfi, Madeline C. 2009. Art. "Slavery." In Encyclopedia of the Ottoman Empire, edited by Gábor Ágoston and Bruce Master, 530-533. New York: Facts on File.

Zürcher, Erik Jan. 1998. "The Ottoman Conscription System, 1844-1914." International Review of Social History 43: 437-449. 